\title{
Radikalizm ve Aşırıcılıktan Terörizme: Siyasal Şiddetin Araçsallaştırılması*
}

\author{
From Radicalism and Extremism to Terrorism: \\ The Instrumentalization of Political Violence
}

\author{
Mehmet KURUM $^{* *}$ - Engin AVCI ${ }^{* * *}$
}

$\ddot{0}$.

11 Eylül saldırılarından sonra, terörist gruplara karşı küresel boyutta yürütülen mücadelenin etkinliği konusundaki tartısmalar, hükûmetleri terörizmle mücadelede yeni stratejiler aramaya itmiştir. Terörizme ilişkin birçok araştırmada, bireylerin neden ve nasıl radikalleştikleri, neden şiddete ve terörizme başvurdukları sorularına cevap aranmıştır. Bu süreçte radikalizm ve aşırıcıllk kavramları, terörizm çalışmalarında önemli bir yer edinmiştir. Terörizmin tanımına ilişkin geleneksel tartısmalardaki muğlak durum radikalizm konusundaki çalışmalara da yansımıştır. Bu makalede radikalizm, aşırıcılık ve terörizm kavramlarına iliş̧kin betimsel bir analiz yapılarak, bu kavramlar arasındaki ilişkilerin ortaya konulmasl, birey ve grupların hangi durumlarda şiddete yöneldiklerinin ve şiddeti araçsallaştırdıklarının incelenmesi amaçlanmıştır. Bu kapsamda, öncelikle radikalizm ve ilgili kavramlar, kavramin tarihsel gelişimi ve kavramla ilgili farkl yaklaşımlar ele alınmıştır. Müteakiben radikal düşünce ve eylemlerin aşırıcıliğa ve

\footnotetext{
${ }^{*}$ Bu makale, Erciyes Üniversitesi tarafindan 31 Ocak-02 Şubat 2018 tarihlerinde Kayseri'de düzenlenen Birinci Uluslararası Sosyal Bilimler Kongresi'nde (USBİK 2018) kısmen sunulan "Terörist Örgütlerin Radikalleşme Süreçleri: Şiddet İçeren Aşırıcılıktan Terörizme Giden Yol" (Radicalization Process of Terrorist Organizations: Path from Violent Extremism to Terrorism) başlıklı bildirinin genişletilmiş versiyonudur.

*** Dr., Jandarma ve Sahil Güvenlik Akademisi, e-posta: mkurum@yahoo.com.

**** Dr., Jandarma ve Sahil Güvenlik Akademisi, e-posta: engavci@ gmail.com.

Geliş Tarihi/Received: 06.06.2018

Kabul Tarihi/Accepted: 06.11.2018
} 
38

Güvenlik Stratejileri

Y11: 14

Say1: 28

terörizme dönüşme sürecinde, şiddetin araç olarak nasll benimsendiği hususlarl ortaya konmuştur.

Anahtar Kelimeler: Radikalizm, Aşırıcılık, Terörizm, Siyasal Şiddetin Araçsallaştırılması, Grup Dinamikleri.

\section{Abstract}

After 9/11 attacks, discussions on the efficiency of global struggle against terrorist groups forced governments to seek new strategies in counterterrorism. In many terrorism studies, researchers tried to find answers to those questions, "how and why individuals are radicalised?" and "why people use violence and terrorism?" During this period, terms of radicalism and extremism have caught the attention of researchers in terrorism studies. The ambiguous situation in traditional discussions on the definitions of terrorism has been reflected in the studies on radicalism. In this article, we aim to make a descriptive analysis about radicalism, extremism and terrorism; to reveal relations among the related terms; to examine in which situations individuals and groups use and instrumentalize violence. Within this context, we handled firstly radicalism and related terms, historical perspective and different approaches on radicalism. Finally, we tried to explain how violence was adopted through the process in which radical thoughts and actions were converted into extremism and terrorism.

Keywords: Radicalism, Extremism, Terrorism, Instrumentalization of Political Violence, Group Dynamics.

\section{Giriş}

11 Eylül saldırılarından sonra, ABD öncülüğünde El Kaide ve bağlantılı gruplara karşı küresel boyutta yürütülen "Terörizme Karşı Savaş" stratejisinin etkinliği konusundaki tartışmalar, hükûmetleri terörizmle mücadelede yeni ve çok boyutlu stratejiler aramaya itmiştir. Özellikle Irak ve Suriye'de faaliyet gösteren terörist gruplara katılan yabancı terörist savaşçılar ile "Yalnız Kurt" olarak tanımlanan teröristlerin 
Batı'da yarattı̆ğ korku ve endişe, terörizmle mücadelede radikalleşme ${ }^{1}$ süreçlerine odaklanılmasına neden olmuştur. 2001 yılından sonra artış gösteren terörizm araştırmaları içerisinde, özellikle "radikalizm" ve "aşırıcılık" (extremism) kavramları ön plana çıkmaya başlamıştır. ${ }^{2}$

2001 öncesi yazılı basında ve akademik yazında nadiren yer alan radikalleşme kavramı, özellikle Londra saldırıları sonrası 2005 ile 2007 yılları arasında Batı Avrupa basınında kendisine önemli bir yer edinmiştir. ${ }^{3} \mathrm{Bu}$ tarihten itibaren birçok Batı Avrupa ülkesinde radikalleşmeye karşı mücadele programları oluşturulmuş ve kavram kurumsallaştırılmıştır. ${ }^{4}$ Afganistan ve Irak'ta yürütülen "Terörizme Karşı Savaş”ta aşırı güç kullanımı ile Ebu Garip ve Guantanamo hapishanelerindeki işkence görüntüleri terör saldırılarının meşru gösterilmesinde birer araç hâline dönüşmüştür. ${ }^{5}$ Batı ülkelerindeki saldırıları gerçekleştiren teröristlerden bir kısmının yine Batı ülkelerinde doğan ve sosyalleşen Müslüman göçmen vatandaşlardan

\footnotetext{
${ }^{1} \mathrm{Bu}$ çalışmada, birbirinin türevleri olan radikal, radikalizm ve radikalleşme kavramları metnin akışına uygun olarak ve atıflardaki orijinallerine sadık kalınarak kullanılmıştır.

${ }^{2}$ Mark Sedgwick, "The Concept of Radicalization as a Source of Confusion", Terrorism and Political Violence, 2010, Cilt: 22, No. 4, 479-494, ss. 480-481; Arun Kundnani, "Radicalisation: The Journey of a Concept" Race \& Class, 2012, Cilt: 54, No. 2, 3-25, s. 4; Alex P. Schmid, Radicalisation, De-Radicalisation, Counter-Radicalisation: A Conceptual Discussion and Literature Review, The International Centre for Counter-Terrorism (ICCT) Research Paper, The Hague, 2013, s. 1; Diego Muro, "What Does Radicalisation Look Like? Four Visualisations of Socialisation into Violent Extremism" Notes Internacionals CIDOB 163, December 2016, s. 2, https://www.cidob.org/en/publications/publication_ series/notes_internacionals/n1_163/what_does_radicalisation_look_like_four_visualisations _of_socialisation_into_violent_extremism (Erişim Tarihi: 06.05.2017); Agnese Macaluso, From Countering to Preventing Radicalization Through Education: Limits and Opportunities, Working Paper 18, The Hague Institute for Global Justice, The Hague The Netherlands, October 2016, s. 1.

${ }^{3}$ Radikalleşme terimine ilişkin 2004 sonrasında akademik ilginin birden arttığını gösteren çalışmalar için bkz. Mark Sedgwick, a.g.e., s. 480; Arun Kundnani a.g.e., s. 7; Colin J. Beck, Radicals, Revolutionaries, and Terrorists, Polity Press, Cambridge UK, 2015, ss. 22-24.

${ }^{4}$ Mark Sedgwick, a.g.e., s. 480.

${ }^{5}$ Arun Kundnani, a.g.e., s. 4.
} 
olmas1, terörizmle mücadelede söz konusu kişilerin nasıl radikalleşerek doğup büyüdükleri ülkelerden nefret edebildikleri ve terör eylemleri

Güvenlik

Stratejileri

Y11: 14

Sayı: 28 gerçekleştirebildikleri konularına odaklanılmasına neden olmuştur. ${ }^{6}$

$\mathrm{Bu}$ dönemde radikalleşme kavramı daha çok Batı merkezli çalışmalarla şekillenmiştir. Bu yönüyle radikalleşme, bireyleri terörizme götüren sürecin açılanmasından çok önleyici stratejiler geliştirilmesinde terörizmle mücadelenin yeni bir aracı olarak görülmüştür. ${ }^{7}$ Benzer şekilde, Neumann da terörizmle mücadelede "bombalar patlamadan önce neler olduğu" ve hangi politik, ekonomik, sosyal ve psikolojik etkilerin terörizm ve siyasal şiddetin temelini oluşturduğuna odaklanılması gerektiğini öne sürmüştür. ${ }^{8}$ Öte yandan Batılı devletler tarafından radikalleşme süreçlerine etki eden faaliyetler ile radikalleşmeye zemin oluşturan sosyal ve politik ortamların ikinci planda bırakıldığını, radikalizm kavramının İslam dininin aşırı yorumlanmasıyla ortaya çıkan şiddet yanlısı kişi veya grupların psikolojik ve teolojik durumlarına indirgendiğini savunan Kundnani ise Avrupa'da yaşayan Müslümanların kültürel ve psikolojik anlamda şiddete eğilimli olduklarına ilişkin temelsiz ve önyargılı yaklaşımlar ortaya çıktığını vurgulamıştır. ${ }^{9}$ Radikalleşme süreçlerine etki eden birçok faktör arasında sosyo-politik yabancılaşma, derinleşen dinî kimlikler ile bazı

${ }^{6}$ Diego Muro, a.g.e., s. 2.

${ }^{7}$ Arun Kundnani, a.g.e., s. 4.

8 Peter R. Neumann, "Introduction", Perspectives on Radicalisation and Political Violence: Papers from the First International Conference on Radicalisation and Political Violence, 17-18 January 2008, International Center for the Study of Radicalisation and Political Violence, Londra, 2008, 3-7, s. 4.

${ }^{9}$ Arun Kundnani, a.g.e., s. 5, 9. Benzer çalışmalar için bkz. Katherine E. Brown ve Tania Saeed, "Radicalization and Counter-Radicalization at British Universities: Muslim Encounters and Alternatives", Ethnic and Racial Studies, 2015, Cilt: 38, No:11, 19521968; S. Lyons-Padilla vd., "Belonging Nowhere: Marginalization \& Radicalization Risk Among Muslim Immigrants" Behavioral Science \& Policy, 2015, Cilt: 1, No. 2, 1-12; Orla Lynch, "British Muslim Youth: Radicalisation, Terrorism and the Construction of the "Other"', Critical Studies on Terrorism, 2013, Cilt: 6, No. 2, 241-261; Tahir Abbas, "The Symbiotic Relationship Between Islamophobia and Radicalisation", Critical Studies on Terrorism, 2012, Cilt: 5, No. 3, 345-358. 
devletlerin dış politikalarına duyulan nefret ve öfke ön sıralarda yer almıştır. ${ }^{10}$ Dinî inançların yanında bilişsel farklılık, kimlik krizi veya gruba bağlılık süreçlerine karşı daha aşırı tepki verilmesini öngören ideolojilerde bireylerin şiddete yönelebileceği şeklinde yaklaşımlar geliştirilmiştir. Bu durumda karmaşık olan radikalleşmeyle mücadelede, teoloji ile bağlantılı olarak duyguların, kimliklerin ve grup dinamiklerinin dikkate alınması gerekliliği ortaya çıkmıştır. ${ }^{11}$

Radikalizm konusundaki çalışmaların bir kısmında terörizmin sosyal, ekonomik ve politik sebeplerini ele alan yukarıdan-aşağıya yaklaşımlar dikkat çekerken, diğer bir kısmında radikaller ile teröristlerin karakteristik özelliklerini ele alan aşağıdan-yukarıya yaklaşımların yer aldığı görülmektedir. ${ }^{12}$ Başlangıçta daha çok psikoloji disiplini içerisinde dar kapsamda ele alınan yaklaşımlar, insan davranışının karakteristik özelliklerini sadece bireysel seviyede tek bir açıdan incelemesi nedeniyle yetersiz kalmıştır. ${ }^{13}$ Bunun yanında radikalizm ile ilgili yapılan kavramsal model çalışmalarında çoğunlukla aşırı düşünce ve inançlara sahip bir grup, belirli bir olay veya birkaç durumu içine alan konular kendilerine özgün mantıksal ve betimsel dönüşüm süreçleri ile ele alınmıştır. ${ }^{14} \mathrm{Bu}$ nedenle, insanların yaşadıkları sosyal, ekonomik, kültürel ve politik çevre içerisinde şekillendiğini dikkate alan ve radikal bireylerin bilişsel ve davranışsal profillerini bireysel seviyede açıklamaya çalışan bilişsel, psikososyal ve psikopatolojik faktörleri içine alan kapsamlı ve çok disiplinli yaklaşımlar geliştirilmesi

\footnotetext{
${ }^{10}$ Alex S. Wilner ve Claire-Jehanne Dubouloz, "Homegrown Terrorism and Transformative Learning: An Interdisciplinary Approach to Understanding Radicalization", Global Change, Peace \& Security, 2010, Cilt: 22, No. 1, 33-51, s. 38.

${ }_{11}^{11}$ Arun Kundnani, a.g.e., ss. 13-14.

${ }^{12}$ Abdrabo Soliman vd., "An Integrative Psychological Model for Radicalism: Evidence from Structural Equation Modeling", Personality and Individual Differences, 2016, No. 95, 127-133, s. 127.

${ }^{13}$ Peter R. Neumann, a.g.e., s. 4.

${ }^{14}$ Randy Borum, "Radicalization into Violent Extremism II: A Review of Conceptual Models and Empirical Research" Journal of Strategic Security, 2011, Cilt: 4, No. 4, 37-62, s. 38.
} 
ihtiyacı ortaya çıkmıştır. ${ }^{15}$

Güvenlik

Stratejileri

Y11: 14

Sayı: 28
Birçok faktörün farklı karışımları şeklinde ortaya çıkan radikalleşme, bireyden bireye değişebilmekte ve farklı ülkelerdeki çalışmalarda değişik şekillerde tanımlanmaktadır. ${ }^{16}$ Terörizmle mücadelede önleyici strateji ve uygulamaların geliştirilmesinde radikalleşme, aşırııılık ve terörizm ilişkisi ile şiddetin araçsallaştırılarak terörizme dönüşüm sürecinin anlaşılması, radikalleşen bireylerin şiddet ve terörizme başvurmasının önlenmesi, şiddete ve terörizme başvuran bireylerin ise bu tutum ve davranışlardan vazgeçirilmesi açısından büyük önem arz etmektedir.

$\mathrm{Bu}$ makalenin amacı, radikalizm, aşırıcılık ve terörizm kavramlarına ilişkin betimsel bir analiz yaparak bu kavramlar arasındaki ilişkileri ortaya koymak, birey ve grupların hangi durumlarda şiddete yöneldiklerini ve şiddeti araçsallaştırdıklarını incelemektir. $\mathrm{Bu}$ kapsamda, makalenin ilk bölümünde zaman ve mekâna göre farklı anlamlar yüklenen radikalizm ve ilişkili kavramlar ele alınmıştır. Daha sonra, radikalizm kavramının tarihsel gelişimi ile literatürde yer alan farklı yaklaşımlar incelenmiştir. Son olarak, radikal düşünce ve eylemlerin aşırıcılığa ve terörizme dönüşme sürecinde şiddetin araç olarak nasıl benimsendiği hususları ortaya konulmuştur.

\section{Radikalizm ve İlişkili Kavramlar}

Radikal kavramının farklı disiplinlerde çoğu zaman bilinçsizce veya değer yüklü olarak kullanılması söz konusu kavramı muğlak ve tartışmalı bir duruma getirmiştir. Bu belirsizlik ve kullanım farklılığ kimin radikal, şiddet yanlısı aşırıcı veya terörist olduğunun tespitini

${ }^{15}$ Peter R. Neumann, a.g.e., s. 4.; Abdrabo, Soliman vd., a.g.e., ss. 127-128.

${ }^{16}$ Riyad Hosain Rahimullah vd., "Understanding Violent Radicalization Amongst Muslims: A Review of the Literature", Journal of Psychology and Behavioral Science, 2013, Cilt: 1, No. 1, 19-35, s. 19; Tahir Abbas, "Ethnicity and Politics in Contextualising Far Right and Islamist Extremism", Perspectives on Terrorism, 2017, Cilt: 11, No. 3, 5461, s. 55; Noor Dahri, "Op-Ed: Mind Space Methodology and De-Radicalisation Model", 13 Mart 2017, http://www.jerusalemonline.com/blogs/noor-dahri/op-ed-mind-spacemethodology-and-de-radicalisation-model-27218, (Erişim Tarihi: 11.04.2017). 
güçleştirmiş ve dolayısıyla radikalizm konusunda yapılan çalışmaların yetersiz kalmasına neden olmuştur. ${ }^{17} \mathrm{Bu}$ nedenle öncelikle radikal, radikalizm ve radikalleşme kavramları ile bu kavramlarla eş anlamda, benzer veya birlikte kullanılan terimlerin tanımlanarak aralarındaki ilişkilerin ortaya konulması gerekmektedir.

Radikal kelimesi "kök, köken, kaynak, temel (root)" anlamında Latince kökenli "radix" kelimesinden türetilmiştir. ${ }^{18}$ Türkçeye Fransızca "köke ait, kökten, siyasette kökten reformları savunan" anlamında kullanılan "radical" kelimesinden geçmiştir. ${ }^{19}$ İngilizce Oxford sözlükte radikal kelimesi sıfat olarak “...kapsamlı veya köklü siyasal veya sosyal değişimi esas alan veya savunan; bir siyasi partinin köklü değişime veya gelişime açık kesimini temsil eden veya destekleyen..." anlamlarında, isim olarak ise "...mevcut politik veya sosyal yapının değişmesi gerektiğini savunan kişi...” anlamını taşımaktadır. Radikalizm ise "...mevcut durumun kapsamlı siyasal veya sosyal reformlar ile değişmesi gerektiğini savunan kişilerin inanç veya eylemleri...” olarak tanımlanmıştır. ${ }^{20}$ Türkçede radikal kavramı "kökten, köktenci", radikalizm kavramı ise "köktencilik" anlamlarına gelmektedir. ${ }^{21}$

Radikalizm ile ilgili anlam karmaşasına yol açan kavramlardan ilki "fundamentalizm"dir. Fundamentalizm, Latince temel anlamına gelen "fundamentum" kökünden türetilmiştir. ${ }^{22}$ Fransızca "fondamentalisme" kelimesinden Türkçeye geçen kavram "kökten dincilik" anlamına gelmektedir. Benzer şekilde "fundamentalist" kelimesi de "kökten

\footnotetext{
${ }^{17}$ Alex P. Schmid, a.g.e., s. 1.

${ }^{18}$ Peter R. Neumann, a.g.e., s. 4.

${ }^{19}$ Etimolojik Sözlük İnternet sitesi, https://www.etimolojiturkce.com/ (Erişim Tarihi: 03.10.2017).

${ }^{20}$ English Oxford Living Dictionaries İnternet sitesi, https://en.oxforddictionaries.com/ (Erişim Tarihi: 03.10.2017).

${ }^{21}$ Türk Dil Kurumu (TDK) İnternet sitesi, http://www.tdk.gov.tr/ Güncel Türkçe Sözlük, (Erişism Tarihi: 03.10.2017).

${ }_{22}$ Ayrıntılı bilgi için bkz. Andrew Heywood, Siyasi İdeolojiler: Bir Giriş, (5. Baskı), (Çev. Ahmet Kemal Bayram vd.), Adres Yayınları, Ankara, 2013, s. 281.
} 

dinci" anlamında kullanılmaktadır. ${ }^{23}$ Kavram ilk olarak 20. yüzyılın başlarında Amerikan Protestanlığı tartışmalarında kullanılmıştır. Evanjelik Protestanlar "The Fundamentals" adıyla yayımladikları kitapçıklar ile İncil'in hatasız, esas ve gerçek olduğuna inandıkları anlamlarını yaymaya çalışmıştır. Zamanla dünyanın farklı yerlerinde farklı anlamlara bürünen ve zit ideolojik özellikler gösteren fundamentalizm, güncel kullanımında İslâmiyet, Yahudilik, Hinduizm, Sihlik ve Budizm ile bağlantılı olarak kullanılmaya başlanmıştır. Bazı fundamentalistler şiddet yanlısı veya muhalif siyasi eylemleri desteklerken, bazıları kanunlara uymayı ve barışçıl davranmayı tercih etmiştir. ${ }^{24}$ Dini sadece kişisel davranış değil sosyal, ekonomik ve siyasi hayatın düzenlenmesini dikte eden temel ve değiştirilemez ilkeler olarak gören fundamentalistlere göre, din, özel alan ile sinırlı kalmamalı; aksine geniş katılımlı sosyal bir yeniden yapılanma politikasını izlemelidir. ${ }^{25}$ $\mathrm{Bu}$ anlamda, ABD'deki Amish ve Heradim ile İsrail'deki aşırı Ortodoks Yahudiler gibi bazı fundamentalist gruplar toplumun yeniden yapılandırılmasından ziyade bu ilkeleri kendi inançları çerçevesinde pasif olarak yaşamayı seçmiştir. ${ }^{26} \mathrm{Bu}$ tür gruplar çoğu inanç sisteminde "1lımlı" (moderate) olarak adlandırılmaya başlanmıştır. Öte yandan bazı fundamentalist gruplar ise aktif çatışmayı veya muhalefet yolunu seçerek ahlaken çürümüş veya bozulmuş olarak nitelendirdikleri devleti ele geçirmeye veya en azından etkilemeye çalışmışıır. ${ }^{27}$

Radikalizme ilişkin açıklanması gereken kavramlardan bir diğeri "ekstrem" kavramıdır. Fransızca "extrême" kelimesinden Türkçeye geçen kavram "aşırı, uç, sıra dışı" anlamına gelmektedir. "Extrême" kelimesinden türetilen İngilizce'deki "extremist" ve "extremism" kelimelerine karşılık Türkçede "aşırıcı" ve "aşırıcılık" kavramları

${ }^{23}$ TDK İnternet sitesi.

${ }^{24}$ Andrew Heywood, a.g.e., ss. 281-283. Farklı fundamentalist hareketler ve özellikleri için bkz. Heywood, a.g.e., ss. 290-300.

${ }^{25}$ A.g.e., s. 285.
${ }^{26}$ A.g.e., ss. $284-285$
${ }^{27}$ A.g.e. ss. $284-285$. 
benimsenmiştir. ${ }^{28}$ İngilizce'de "extremist”; “özellikle yasa dış1, şiddet veya başka aşırı faaliyetleri savunan aşırı politik veya dinî düşüncelere sahip kişileri”" nitelemek için kullanılmaktadır. ${ }^{29}$ İngiliz hükûmeti "extremism" kavramını "demokrasi, hukukun üstünlüğü, bireysel özgürlükler, farklı inanç ve düşüncelere karş1lıklı saygı ve hoşgörü gibi İngilizlerin temel değerlerine sözlü veya aktif muhalif olma" şeklinde tanımlamıştır. $\mathrm{Bu}$ anlamda, günümüzde toplumun mevcut değer ve inançlarına karşı gelme/muhalefet etme olarak tanımlanan "extremism" (aşırıcılık) de radikalizmin bir türü olarak ortaya çıkmaktadır. ${ }^{30}$ Bunun yanında, son dönem güvenlik ve terörizm alanyazınında "extremism" (aşırıcılık) ve "violent extremism" (şiddet içeren aşırıcılık) kavramlarının aradaki nüansa bakılmaksızın birbirlerinin yerine kullanıldıklarını belirtmek isabetli olacaktır.

Radikalizm ile ilişkili diğer bir kavram "fanatizm"dir. Fransızca "fanatisme" kelimesinden Türkçeye geçen terim "bağnazlık" anlamına gelmektedir. Günlük kullanımda daha çok spor müsabakalarında bir takıma veya gruba mensup "taraftar" anlamını taşıyan "fanatik" kelimesi, Türkçe sözlükte "bir düşünceye, bir inanışa aşırı ölçüde bağlanıp ondan başka bir düşünce ve inanışı kabul etmeyen, mutaassıp" anlamındaki bağnaz kelimesi ile tanımlanmıştır. ${ }^{31}$ İngilizce sözlükte "fanatik" kelimesi isim olarak "özellikle aşırı dinî veya politik bir amaç için aşırı ve tek boyutlu bir şekilde şevk ve istek ile dolu olan kişi; belirli bir faaliyet veya konu ile saplantılı bir şekilde ilgilenen ve coşkulu olan kişi" şeklinde tanımlanmış; sıfat olarak ise "aşırı şevk ve istekli veya ifadeli olma" şeklinde tanımlanmıştır. ${ }^{32} \mathrm{Bu}$ kapsamda, fanatizmde belirli bir konuya ilişkin duygu yoğunluğu ve coşku içerisindeki bir saplantı ile başka inanç, düşünce ve duygular doğrudan reddedilmektedir.

\footnotetext{
${ }^{28}$ TDK İnternet sitesi.

${ }^{29}$ English Oxford Living Dictionaries İnternet sitesi, https://en.oxforddictionaries.com/ (Erişim Tarihi: 03.10.2017).

${ }^{30}$ Agnese Macaluso, a.g.e., s. 3.

${ }^{31}$ TDK İnternet sitesi.

${ }^{32}$ English Oxford Living Dictionaries İnternet sitesi.
} 
Güvenlik

Stratejileri

Y11: 14

Say1: 28

Örneğin; hayvan hakları savunuculuğundan çevre konularına kadar farklı alanlarda ortaya çıkabilen fanatizm fundamentalizm içerisinde de görülebilir.

Radikalizm ile ilişkili olarak açıklanmasına ihtiyaç duyulan son kavram "terörizm" kavramıdır. Son dönem terörizm çalışmalarında sıkça karşılaşılan radikalizm kavramı "terörizm" ile iç içe kullanılabilmekte, hatta terörist faaliyetlerde bulunan bazı kişi ve gruplar radikal olarak nitelendirilebilmektedir. ${ }^{33}$ Birbiriyle ilişkili olan bu iki kavram, aslında farklı anlamları ifade etmektedir. ${ }^{34}$ Terör kelimesi "ürpermek ve ürpermeye neden olmak" anlamına gelen Latince "terrere" sözcüğünden türemiştir. ${ }^{35}$ Fransızca Petit Robert sözlüğünde terör kelimesi "bir toplumda bir grubun halkın direnişini kırmak için yarattığı ortak korku" yani "terör ile yönetme" anlamında tanımlanırken, terörizm kelimesi Larousse sözlükte "politik amaçlar için sistematik şiddetin kullanılması" şeklinde tanımlanmıştır. ${ }^{36}$ Türkçeye Fransızca "terreur" kelimesinden geçen terör kelimesi "yıldırma, cana kıyma ve malı yakıp yıkma, korkutma, tedhiş" anlamına gelmektedir. ${ }^{37}$

Terör kavramını akademik yazında ilk kez tanımlayanlardan biri olan Thornton, terörü "şiddet kullanma ya da şiddet tehdidi içeren normal dışı yollarla siyasal davranışları etkilemek üzere tasarlanmış sembolik fiil" şeklinde tanımlamıştır. Yazar, ayrıca halk desteğinin az olduğu durumlarda, özellikle mevcut yönetime bağlı olan harekete geçmemiş grupların harekete geçirilmesi için mevcut yönetimin istikrarsızlaştırılarak halk ile bağlarının koparılması, başka bir ifadeyle

\footnotetext{
${ }^{33}$ Diego Muro, a.g.e., s. 4.

${ }^{34}$ Riyad Hosain Rahimullah vd., a.g.e., s. 20; Diego Muro, a.g.e., s. 1; Agnese Macaluso, a.g.e., s. 3.

${ }^{35}$ Paul Wilkinson, Political Terrorism, The Macmillan Press, Londra, 1974, s. 9.

${ }^{36}$ Gérard Chaliand ve Arnaud Blin. "The Invention of Modern Terror", Gérard Chaliand ve Arnaud Blin (Eds.), The History of Terrorism: From Antiquity to Al Qaeda, (Çev. Edward Schneider, Kathryn Pulver ve Jesse Browner), University of California Press Ltd., Londra, 2007, 95-112, s. 100.

${ }^{37}$ Türk Dil Kurumu (TDK), Türkçe Sözlük, (10.Bask1), Ankara, 2005.
} 
terör ile siyasal davranışların etkilenmesi gerektiğini vurgulamıştır. Thornton, terör tanımında yer alan "şiddet" ve "şiddet tehdidi" unsurunun terörist faaliyetlerin en önemli unsuru olduğunu, şiddet içermeyen hiçbir faaliyetin terörizm olarak nitelendirilemeyeceğini ifade etmiştir. ${ }^{38}$ Bozdemir, terörizmi, "siyasal amaçlar için örgütlü, sistemli ve sürekli terör kullanmayı yöntem olarak benimseyen bir strateji anlayışı" olarak tanımlamıştır. Bir sürecin terörizm olarak tanımlanması ancak belli bir hedefe yönelmiş birbirleriyle bağlantılı bir dizi terör olayının gerçekleşmesine bağlıdır. ${ }^{39}$ Sonuç olarak; terör belirli bir irade gerektirmeden de ortaya çıkabilen, düzensiz, örgüte gerek duymayan, çoğu kez anlık veya kısa süreli şiddeti ifade ederken, terörizm terörün sistematik, iradi, çoğu kez örgütlü ve uzun süre kullanımını içeren bir kuralsız savaş ve propaganda tekniği ile stratejiye işaret etmektedir. ${ }^{40}$

\footnotetext{
${ }^{38}$ Thomas Perry Thornton,"Terror as a Weapon of Political Agitation", Herry Eckstein (Ed.), Internal War: Problems and Approaches, The Free Press, New York, 1964, 71-99, ss. 71-78.

${ }^{39}$ Sertaç Başeren, “Terörizm ve Uluslararası İlişkiler”, Stratejik Araştırmalar Dergisi, Subat 2003, Cilt: 1, No. 1, 51-58, s. 51.

${ }_{40}$ Türkiye Barolar Birliği, Türkiye ve Terörizm, Rapor, TBB Yayınları, Ankara, Haziran 2006, s. 4.
} 


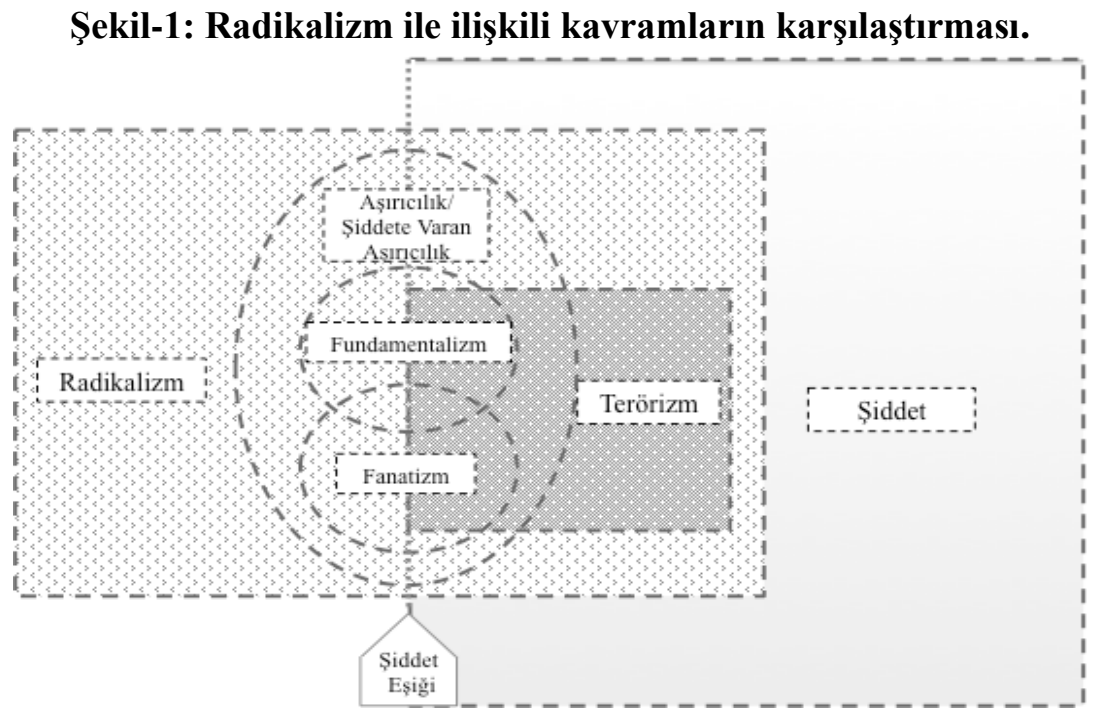

Günümüzde aralarındaki nüansa dikkat edilmeksizin yakın anlamlarda veya birbirlerinin yerine kullanılan radikalizm, aşırıcılık, fundamentalizm, fanatizm ve terörizm kavramları arasındaki ilişkiler Şekil-1'deki gibi gösterilebilir. Öncelikle kavramların sınırları ile kapsamlarının belirlenmesindeki güçlükler kabul edilmelidir. Bununla birlikte, kavramsal ilişkiye dair en önemli belirleyici unsurun "şiddet eşiği" olduğunu vurgulamak gerekir. $\mathrm{Bu}$ çerçevede terörizm ve radikalizm ilişkisine değinmek gerekirse; radikalizmin fikirleri, terörizmin eylemleri ifade ettiği söylenebilir. Her terörist radikaldir, fakat bütün radikaller terörist olmayabilir. Terörizm şiddet ifadesinin nihai noktası iken; radikalizm zaman içinde siyasal şiddete ve terörizme dönüşebilmektedir. ${ }^{41}$ Radikal düşüncelere ve fikirlere sahip çoğu kişi terörizme başvurmazken, çoğu terörist derin ideolojik düşüncelere sahip olmayabilir ve geleneksel şekilde radikalleşmeyebilir. Şiddeti meşrulaştıran

${ }^{41}$ Diego Muro, a.g.e., s. 1; Abdrabo Soliman vd., a.g.e., s. 127. 
aşırı uç inanç ve düşüncelerin uyarlanması ve geliştirilmesiyle ortaya çıkan radikalleşme, terörizme giden yollardan sadece biridir. Bu noktada, insanların terörizm faaliyetlerine nasıl dâhil oldukları, neden terörizm faaliyetleri içerisinde kalmaya devam ettikleri ve terörizmden nasıl uzaklaştıkları sorularının cevapları "şiddet içeren aşırılığa giden radikalleşme süreçleri" kapsamında ortaya konulabilir. ${ }^{42}$

"Aşırıcıllk" kavramı ile aşırıcılık içerisinde yer verilen "fundamentalizm" ve "fanatizm" kavramları ise radikalleşmenin birer çeşidi olarak ortaya çıkmaktadır. Öncelikle "aşırıcılık" ve "şiddet içeren aşırıcılık" kavramları irdelendiğinde; bireylerin her türlü inanç, fikir ve eylemlerinde aşırı tutum ve davranış sergileyebildiği, burada belirleyici olan unsurun da "şiddet eşiği" olduğu söylenebilir. "Aşırıcılık" şiddet eşiğini aştıktan sonra, yani "şiddet içeren aşırıcılık" hâlini aldıktan sonra hedeflenen ideolojik veya siyasi amaç bağlamında kendisine terörizm kavramının alanı içerisinde yer bulabilir. Aksi hâlde, siyasi amaç gütmeyen bir eylem ve davranışın şiddet eşiğini aşsa bile terörizm kapsamına girmesi mümkün değildir. Aşırıcılığın içerisinde yer verilen "fundamentalizm" ve "fanatizm" ilişkisinde de şiddet belirleyici bir unsur olarak ön plana çıkmakla birlikte fundamentalistlerin bir kısmı fanatik davranışlar gösterebilmekte ve terörizmi strateji olarak benimseyebilmektedir. Sonuç olarak radikalizm, aşırıcılık, fundamentalizm ve fanatizm kavramları, ulaşılmak istenen amaç ve hedef bağlamında şiddeti sistematik araç olarak kullanılmaya başladıkları noktalarda terörizm kavramının alanı içerisinde yer bulabilmektedir. Öte yandan, şiddet alanında savaş ve organize suçlar ile bir kısım asayiş suçlarının yer alabileceğini belirtmek gerekir. Devletler arasinda veya devlet olarak tanınan gruplar ile devletler arasında şiddet içeren çatışmaları kapsayan savaşlar ile çoğunlukla suç bilimi alanında konu edilen, siyasi amaç yerine kâr ve menfaat amacı gütmeleriyle terörist örgütlerden ayrılan şiddet içeren organize suçlar ile adi suçlar da şiddet alanının önemli bir kısmını oluşturur.

\footnotetext{
${ }^{42}$ Randy Borum, a.g.e., s. 38.
}

Güvenlik Stratejileri

Y11: 14

Say1: 28 


\section{Radikalizm Kavramının Tarihsel Gelişimi ve Kavramsal Yaklaşımlar}

Y11: 14

Radikalizm kavramı 19. yüzyıldan itibaren sosyal ve politik reformları desteklemeyi amaçlayan politik gündem çerçevesinde yaygın olarak kullanılmaya başlamıştır. $\mathrm{Bu}$ dönemde, kral taraftarlarına karşı cumhuriyetçiliği savunan birçok siyasi parti kendisini radikal olarak tanımlamış; herkese eşit oy hakkı tanınan demokratik bir sistemi savunmuştur. $\mathrm{Bu}$ dönemde çoğunlukla şiddet içermeyen, liberal, bürokrasi karşıtı, demokrasi taraftarı, yenilikçiliği ve değişimi öngören reformist düşünceleri ifade etmek için pozitif anlamda kullanılan radikalizm kavramı günümüzde anti-liberal, fundamentalist, anti-demokratik ve geçmişe dönüşü çağrıştıran zit anlamları nitelemeye başlamıştır. ${ }^{43}$

Radikalleşme kavramının akademik alanda veya devletler bazında ortak kabul edilmiş bir tanımı yoktur. ${ }^{44}$ Avrupa Komisyonu tarafindan 2006 yılında oluşturulan "Şiddet İçeren Radikalleşme Uzmanlar Grubu" (The Expert Group on Violent Radicalisation) tarafından terörizm özelinde "radikalleşme, bağlama göre şekillenen bir olgu" olarak nitelendirilmiştir. İdeolojik ve psikolojik dürtülerin yanında küresel, sosyolojik ve politik dürtülerinde radikalleşme süreçlerini etkilediği ifade edilmiştir. $\mathrm{Bu}$ kapsamda, şiddet içeren radikalleşme işlevsel olarak kısaca "kendini terörizm ile ortaya koyan aşırılığın sosyalleştirilmesi” şeklinde tanımlanmıştır. ${ }^{45}$

Radikalleşme, şiddet içeren eylemlerin yanında geleneksel olmayan düşünceleri de kapsayan geniş bir anlama sahiptir. Buna rağmen, tarihsel olarak özellikle Avrupa'da politik aşırıcılık anlamında sıklıkla kullanılmış olmasına rağmen, son yıllarda kavram sadece

${ }^{43}$ Alex P. Schmid, a.g.e., ss. 6-7; Agnese Macaluso, a.g.e., s. 2.

${ }^{44}$ Alex P. Schmid, a.g.e., s. 5.

${ }^{45}$ European Commission's Expert Group on Violent Radicalisation, "Radicalisation Processes Leading to Acts of Terrorism", 15 May 2008, http://www.rikcoolsaet.be/files/ art_ip_wz/Expert\%20Group\%20Report\%20Violent\%20 Radicalisation\%20FINAL.pdf, s. 7, (Erişim Tarihi: 12.10.2017). 
cihatç1lık (jihadism) ve dinî aşırılık anlamına indirgenmiştir. ${ }^{46}$ Roy'un "İslamın Radikalleşmesi” yerine tercih ettiği "Radikalleşmenin İslamlaşması" şeklindeki ifadesi, kavramın dönüşümüne güzel bir örnek teşkil etmektedir. ${ }^{47}$ Radikalizm kavramının nasıl tanımlanacağı ve ele alınacağ 1 kim tarafından, nerede ve ne zaman kullanılacağına bağlı olarak değişebilmektedir. ${ }^{48}$ Radikal hareketler, normal olarak kabul edilen sosyal hareketlerin dışındaki düşünceler ve eylemler olarak nitelendirilebilir. Terörizm kavramına ilişkin tartışmalarda olduğu gibi "birine göre radikal olan kişi, bir başkasına göre normal" kabul edilebilir. Bu şekilde, bir zaman veya yerde radikal olarak görülen, başka bir zaman veya yerde radikal olarak görülmeyebilir. ${ }^{49}$

Konuyu analitik bir yaklaşımla ele alan Moskalenko ve McCauley, aktivizmi "yasal ve şiddet içermeyen politik eylemlere katılmaya hazır olma" olarak tanımlarken, radikalizmi yasa dışı ve şiddet içeren politik eylemlere katılmaya hazır olma" şeklinde tanımlamıştır. ${ }^{50}$ Radikalizmin yasa dışı eylemler olarak nitelendirilmesi, yasal ve yasa dışı standartların uluslararası hukuk standartlarına göre mi yoksa herhangi bir devletin hukuk standardına göre mi ele alınacağı sorusunu ortaya çıkarmaktadır. Bu noktada, bir eylem veya faaliyet yasal aktivizm veya yasa dışı radikalizm olarak nitelendirilebilirken; devletlerin yönetim biçimi ister demokratik ister otokratik olsun, yeni bir kanun değişikliği ile bir anda yasal olan bir eylem veya faaliyet yasa dışı, yasa dışı bir eylem veya faaliyet yasal duruma dönüşebilmektedir. Bu şekilde, son iki yüzyılda hem şiddete başvurmayanlar, hem de şiddete başvuranlar, radikal olarak ve bunların eylem ile faaliyetleri de hem yasal, hem de

\footnotetext{
${ }^{46}$ Agnese Macaluso, a.g.e., ss. 2-3.

${ }^{47}$ Olivier Roy, "The Islamization of Radicalism", Rosa Luxemburg Stiftung, http://www.rosaluxna.org/wp-content/uploads/2016/06/Newsletter-oliver-roy-ENG-26-0116.pdf (Erişim Tarihi: 13.09.2018).

${ }^{48}$ Alex P. Schmid, a.g.e., s. 6.

${ }^{49}$ Colin J. Beck, a.g.e., s. 37.

${ }^{50}$ Sophia Moskalenko ve Clark McCauley, "Measuring Political Mobilization: The Distinction Between Activism and Radicalism," Terrorism and Political Violence, Cilt: 21, No. 2, 2009, 239-260, s. 240.
} 
52

Güvenlik

Stratejileri

Y11: 14

Sayı: 28

yasa dışı radikalizm olarak nitelendirilebilmiştir. ${ }^{51}$

Radikalizm kavramı birçok devlette kurumsal olarak farklı şekillerde tanımlanmıştır. ${ }^{52}$ Bazı devletlerin ilgili güvenlik kurumlarınca radikalleşme ile yapılan tanımlar aşağıdadır:

- ABD İç Güvenlik Departmanı (US Department of Homeland Security [DHS]) "sosyal değişim yaratmak için şiddet kullanma, şiddet kullanmayı destekleme veya kolaylaştırmayı da içine alan aşırı uç inanç sistemini hayata geçirme süreci”,

- Danimarka Güvenlik ve İstihbarat Servisi (Danish Security and Intelligence Service [PET]), "bir kişinin özel politik/ideolojik amaçlarına ulaşmak için terörizm dâhil demokratik olmayan yöntemlerini veya şiddet araçlarını artan bir şekilde kullanma süreci”,

- Hollanda Genel İstihbarat ve Güvenlik Servisi (The Netherlands General Intelligence and Security Service [Algemene Inlichtingen-en Veiligheidsdienst-AIVD]), "mevcut demokratik yasal düzene tehlike oluşturacak şekilde demokratik yasal düzenin fonksiyonlarına zarar verecek demokratik olmayan metotları kullanarak toplumda kapsamlı değişiklikler (aktif olarak) gerçekleştirme ve/veya bunu destekleme",

- İsveç Güvenlik Servisi (Swedish Security Service [Säpo]), "toplumda radikal değişikliği tanıtmayı öngören ideolojik veya dini aktivizm süreci ve politik amaçlara ulaşmak için bir kişi veya grubun şiddeti kullanması, desteklemesi veya savunması süreci" olarak tanımlamıştır. ${ }^{53}$

Yukarıdaki radikalleşme tanımlarında, ABD'de aşırı uç inanç sistemini benimseme, Danimarka'da demokratik olmayan araçları veya şiddet araçlarını kullanma, Hollanda'da toplumda kapsamlı değişikliği amaçlama ve İsveç’te politik amaçlar için şiddeti kullanma hususlarına

\footnotetext{
51 Alex P. Schmid, a.g.e., ss. 7-8.

${ }^{52}$ Mark Sedgwick, a.g.e,. s. 483; Alex P. Schmid, a.g.e., s. 12.

${ }^{53}$ Alex P. Schmid, a.g.e., s. 12.
} 
vurgu yapılmıştır. ${ }^{54} \mathrm{Bu}$ tanımlamalarda "şiddet" unsuru temel referans olarak ortaya çıkmıştır. Fakat ABD'de yapılan tanımda şiddet unsuru merkezî konumda aşırı uç inanç sistemi ile ilişkilendirilirken; Danimarka ile Hollanda'da yapılan tanımlamalarda şiddet içermeyen ve demokratik olmayan yöntemler radikalizm içerisinde değerlendirilmiştir. Ayrıca Danimarka'da terörizm dâhil şiddet, radikalizmin bir unsuru iken, şiddet içermeyen demokratik eylemler de radikalizm içerisinde yer almıştır. Hollanda'da ise şiddet, sadece demokratik sisteme zarar verme içerisinde sınırlandırılmış ve demokratik sisteme zarar veren ve şiddet içermeyen demokratik olmayan yöntemler radikalizmin unsurları olarak değerlendirilmiştir. ${ }^{55}$ İsveç'te ise hem radikal değişimi öngören ideolojik ve dinî aktivistlik (şiddet içermeyen aşırılık yanlısı eylem ve faaliyetler) hem de şiddetin araç olarak kullanılması, desteklenmesi ve savunulması radikalizm içinde ele alınmıştır.

Radikalizm kavramı, düşünceler ve eylemler arasındaki ilişkiler bağlamında da sorunlar taşımaktadır. Radikalizm yaklaşımlarında devletlerin bir kısmı belirli ideoloji veya düşünce ve inancı tehdit olarak kabul ederken; diğer bir kısmı herhangi bir ideoloji veya düşünce ve inanca atıfta bulunmadan şiddet içeren aşırıcılığın desteklenmesini tehdit olarak kabul etmektedir. Bu noktada, bir şeyin şiddete sebep olması tehdit olarak tanımlanırken; demokratik değerlere muhalif ancak şiddete neden olmayan durumların tehdit olarak kabul edilip edilemeyeceği konuları belirsiz kalmaktadır. ${ }^{56}$ Örneğin, 2006 yılında Avrupa Komisyonu'nda yapılan tanımlamada radikalleşme "insanları terörizm eylemlerine yöneltebilen düşünceler, görüşler ve fikirleri kapsayan bir olgu" olarak tanımlanmıştır. Bu tanımlamada ilk olarak hangi koşulların kişileri terörizme yöneltebileceği hususu net değildir. İkinci olarak, ideolojiyle ilişkili olan "düşünceler, görüşler ve fikirler" ifadesi çok geniş ve belirsizdir. Üçüncü olarak, radikalleşme, terörizm

\footnotetext{
${ }^{54}$ A.g.e., s. 12.

${ }^{55}$ Mark Sedgwick, a.g.e,. s. 484.

${ }^{56}$ A.g.e,. s. 484.
} 
54

Güvenlik Stratejileri

Y11: 14

Sayı: 28

dışında da çeşitli şekillerdeki çatışmalara neden olabilmektedir. ${ }^{57}$ Benzer şekilde, radikalizm ile ilgili bazı tanımlarda, ABD'de aşırı uç inanç sistemleri olan düşünceler tehdit olarak kabul edilirken; İsveç'te ideolojik veya dinî aktivizm sürecinde olduğu gibi hem şiddet içermeyen, hem de şiddet içeren eylemler tehdit olarak kabul edilmiştir. $^{58}$ Radikalizm kavramını mutlak şekilde tanımlamaya yönelik yaklaşımların subjektiflikleri ve tutarsızlıkları, tarihsel ve konumsal olarak farklı şekillerde anlamlandırılan kavramın göreli olarak ele alınması gerektiği sonucunu ortaya çıkarmıştır. Bu bağlamda, radikalizmin süreç olarak ele alınması ve bu süreçte normal kabul edilenin ne olduğunun ortaya konulması gerekmektedir. ${ }^{59}$

Radikal kavramını insanlar, fikirler ve eylemlerin bir sıfatı olarak tanımlayan Beck, radikalizmin hangi aktörlerin potansiyel olarak radikal olabileceği, radikal strateji ve eylemlerin özelliklerinin neler olacağı ve hangi fikirlerin, iddiaların ve amaçların radikal olarak nitelendirilebileceği konularını içine alacak şekilde kavramsallaştırılması gerektiğini ifade etmiştir. Bu çerçevede, radikalizm "toplumda genel kabul gören politik ortamın dışında sosyal, kültürel, ekonomik ve politik yapılarda önemli ölçüde değişikliği öngören ve kurumsal araçların ötesinde araçları kullanan herhangi bir aktörün mücadelesi" olarak tanımlanmıştır. ${ }^{60}$ Burada kurumsal araçlar ile kurumsal politikaların içindeki oy kullanma, lobicilik, yasama gibi faaliyetler ifade edilirken; kurumsal araçların ötesindeki araçlar ile protesto, boykot, oturma eylemi, sabotaj, şiddet vb. eylemler ifade edilmektedir. $\mathrm{Bu}$ şekilde kurumsal olmayan araçların kullanılmaya başlanması radikalizme doğru bir eğilime işaret etmektedir. ${ }^{61}$

Tarihsel süreçteki yaklaşımlar ve politik fikirler dikkate alındığında, temel olarak radikalizmin açıklanmasında, "düşünce veya

\footnotetext{
${ }^{57}$ Alex P. Schmid, a.g.e., s. 12

${ }^{58}$ Mark Sedgwick, a.g.e,. s. 484; Alex P. Schmid, a.g.e., s. 12.

${ }^{59}$ Mark Sedgwick, a.g.e,. ss. 490-491.

${ }^{60}$ Colin J. Beck, a.g.e., ss. 38-39.

${ }^{61}$ A.g.e., ss. 39-40.
} 
tutum" ile "eylem veya davranış" arasındaki farkın çok iyi ayırt edilmesi gerekmektedir. "Düşünce veya tutum", tamamen farklı bir alternatifin radikal olarak görülmesinin yanında, mevcut durumun kabul edilemez olduğu inancına dayanan köklü politik değişikliklerin savunulması olarak ifade edilebilir. "Eylem ve davranış" kavramları ise hükûmet ve toplum için sistemi dönüştüren, radikal bir çözümü getirmek için savunulan araçlar olarak nitelendirilebilir. Bunlar şiddet içermeyen ve demokratik (ikna ve reform yoluyla) ya da şiddet içeren ve demokratik olmayan (zorlama ve devrim yoluyla) araçlar olabilir. ${ }^{62}$ Dolayısıyla terörizme giden süreçteki ayırt edici unsurun şiddet ve şiddetin araçsallaştırılması olduğu söylenebilir.

\section{Radikalizm, Aşırıcılık ve Terörizm: Şiddetin Araçsallaştırılması}

Radikalizm ve aşırıcılığın, şiddetin araç olarak kullanıldığı veya kullanılmadığı eylem veya davranışlar olmak üzere iki boyutta ele alınabildiği yukarıda ifade edilmişti. Bununla birlikte, terörizmde amaçlara ulaşmak için şiddet ve şiddet tehdidi sistematik olarak kullanılmakta; şiddet temel stratejik araç olarak ortaya çıkmaktadır. Bu noktada, radikal ve aşırı hareketlerin gelişim süreçlerinde şiddetin sistematik araç olarak kullanılmaya başlaması, söz konusu hareketlerin terörizme dönüşmesi anlamına gelmektedir. Dolayısıyla, radikal ve aşırıcıların tümünün, şiddete başvurmadıkları müddetçe, terörist olarak nitelendirilmeleri doğru olmayacaktır. ${ }^{63}$

Etnik ayrılıkçılık, kimlik çatışmaları, modernleşme, aşă̆ılama, şiddet içeren söylemler ve sosyal adaletsizlik gibi farklı olguların neden olduğu politik şikâyetlerin terörizme dönüşme potansiyeli vardır. Fakat çeşitli şikâyetleri olan insanların gerçek hayatta çok azı

\footnotetext{
${ }^{62}$ Alex P. Schmid, a.g.e., s. 8.

${ }^{63}$ Mark Sedgwick, a.g.e,. s. 483; Randy Borum, a.g.e., s. 38; Alex P. Schmid, a.g.e., s. 8; Agnese Macaluso, a.g.e., s. 4.
} 
terörizme yönelmektedir. ${ }^{64} \mathrm{Bu}$ noktada, radikal grupların şiddete nasıl

Güvenlik Stratejileri

Y11: 14

Say1: 28 yöneldikleri sorusu önem kazanmaktadır; çünkü radikal ve aşırı amaçları olan bir grup her zaman şiddete yönelmeyebilir. Bunun yanında, şiddet yanlısı gruplar içinde yer alma ve şiddet eylemlerine karışma, radikal amaçlardan bağımsız olarak kişiler arası ilişkiler ve gruba bağl1lık gibi başka nedenlerle de ilişkili olabilir. Bu nedenle, birey, grup ve organizasyon seviyelerinde çeşitli süreçleri ihtiva eden radikalleşme, analitik olarak farklı mekanizma ve örnekler kapsamında, radikalleşme süreçlerinin yaşandığ 1 sosyal ve politik bağlam ile birlikte ele alınmalıdır. Bu şekilde radikalleşme, şiddeti benimseyen grupların çevreleriyle veya düşman aktörlerle etkileşimleri sonucunda gelişir. Radikalleşme sürecinde protesto grupları ile güvenlik güçleri arasında gerginlik artabileceği gibi, farklı sosyal grupların karşı karşıya gelmeleri durumunda da gerginlik tırmanabilir. $^{65}$

Radikal düşünce ve davranışlara sahip olan kişilerin hepsinin şiddete yönelmediği dikkate alındığında, radikaller ile aşırıcıların bazı farklılıklarının yanında bazı ortak özelliklere de sahip oldukları görülmektedir. ${ }^{66}$ Radikal düşüncelere sahip kişilerin şiddeti tasvip etmeleri veya etmemeleri, demokratik olmaları veya olmamaları mümkündür; fakat aşırıcılar hiçbir zaman demokratik değildir. Bunun yanında, aşırıcılar farklı düşüncelere tolerans göstermez ve politik güç için zor kullanılabileceğini öngörür. Ayrıca aşırıcıların esneklikten uzak ve kapalı olan düşünce yapıları dünyayı "bizden olanlar" ve "karşı taraftakiler" şeklinde tek taraflı görmeye meyillidir. Diğer taraftan radikal düşüncelere sahip kişiler bir sorunun kökenini tarihsel

${ }^{64}$ Eteri Tsintsadze-Maass ve Richard W. Maass, “Groupthink and Terrorist Radicalization”, Terrorism and Political Violence, 2014, Cilt: 26, No. 5, 735-758, s. 736; Agnese Macaluso, a.g.e., s. 4.

${ }^{65}$ Donetella Della Porta ve Gary LaFree, "Guest Editorial: Processes of Radicalization and De-Radicalization", International Journal of Conflict and Violence (IJCV), 2012, Cilt. 6, No. 1, 4-10, s. 7.

${ }^{66}$ Alex P. Schmid, a.g.e., s. 8. 
olarak araştırmayı öngörerek rasyonelliğe ve faydacı (pragmatik) düşünceye açık olma eğilimindedir. Radikal düşüncelere sahip militanlar normalleşebilirken; aşırıcıların normalleşme ihtimali çok daha az olduğu söylenebilir. Dolayısıyla radikaller yeniliklere açık ve açık fikirli olarak nitelendirilirken aşırıcılar farklı fikirlere kapalı olarak tanımlanabilir. Burada radikalleşme sürecinin radikalizme dönüşmesinden ziyade, radikalleşme sürecinin şiddeti politik araç olarak benimseyen aşırıcıllğa ve sonrasında terörizm ile soykırım gibi diğer şiddet eylemlerine dönüşmesi asıl tehdit olarak ortaya çıkmaktadır. ${ }^{67}$

Radikalleşme süreci sol ve sağ ideolojik, anarşist, etnik milliyetçi veya dinî olsun terörizmin bütün türlerinde ortaya çıkabilmektedir. ${ }^{68}$ Terörizme başvurmak için haklı gerekçeleri olduğunu öne süren teröristlerin büyük çoğunluğu derin ideolojik anlayışa sahip değildir ve geleneksel anlamda radikalleşmiş olmayabilir. Şiddeti meşrulaştıran aşırı inançlar geliştirilerek veya benimsenerek radikalleşme, terörizme giden yollardan sadece biri olarak ortaya çıkabilir. ${ }^{69}$

Bu noktada radikalizmin aşırıcılığa dönüşen özelliklerinin ortaya konulması gerekmektedir. Aşırıcıların kalıplaşmış ve dogmatik (inanca dayalı) ideolojik öğretiye dayalı homojen bir toplum yaratmak için mücadele ettikleri ve bunu bütün muhalif düşünceleri bastırarak ve azınlık grupları tahakküm altına alarak gerçekleştirmeye çalıştıkları söylenebilir. $\mathrm{Bu}$ şekilde aşırıcılar, dogmatik düşüncelerden bağımsız olarak farkl11ıkları kabul eden ve aklın gücünü esas alan radikallerden ayrılır. Demokratik toplumlar dikkate alındığında (şiddeti benimseyen) aşırıcı gruplar, hareketler ve partilerin bazı özellikleri:

- anayasal düzen karşıtlığı, anti-demokratik, çoğulculuk karşıtlığ1, otoriterlik,

\footnotetext{
${ }^{67}$ A.g.e., s. 10.

${ }^{68}$ Diego Muro, a.g.e., s. 2.

${ }^{69}$ Randy Borum, a.g.e., s. 38.
} 
58

Güvenlik

Stratejileri

Y11: 14

Say1: 28

- fanatik, tolerans göstermeyen, taviz vermeyen, tek taraflı siyah veya beyaz düşünceye sahip olma,

- amaçların araçları meşrulaştırdığı düşüncesini kabul ederken hukukun üstünlüğünü ve hukuk devletini reddetme,

- amaçlarını gerçekleştirmek için firsat bulduklarında düşmanlarına ve muhaliflerine karşı büyük çapta siyasal şiddet dâhil her türlü aracı kullanılabilme şeklinde ifade edilebilir. ${ }^{70}$

Aşırıcıların söz konusu özellikleri ve yöntem tercihleri güç elde ettiklerinde çoğunlukla totaliterliğe yönelmelerini sağlar. ${ }^{71}$ Radikal düșüncelerin aşırıcılığa dönüșmeye başladığı noktada amaçsal olarak mevcut otoriteyi reddetme ve düşünsel olarak tek biçimlilik ön plana çıkarken araçsal olarak kendi düşüncelerinin karşısında olanlara karşı şiddetin kullanılması meşru görülmeye başlar.

Öncelikle mevcut duruma tepki olarak düşünsel boyutta başlayan radikalizm, daha sonra hem düşünsel, hem de eylemsel boyutlarda aşırıcılığa doğru evrilebilir. Radikal hareketler düşünsel ve eylemsel boyutlarda aşırılığa evrildiğinde, amaç veya hedeflere ulaşmak için etki tepki mekanizmalarına bağlı olarak önce şiddet içermeyen, daha sonra şiddet içeren araçlar kullanılmaya bașlar. Fakat bu noktada radikal hareket içinde şiddet içeren araçların meşru kabul edilebileceği bir zeminin oluşması gerekmektedir. Söz konusu meşruluk bazen düşman olarak tanımlanıp mücadele edilen aktör ve grupların şiddet kullanımına bağlı olarak etki-tepki mekanizması içerisinde gelişirken; bazen de amaç ve hedefleri oluşturan ideoloji ve inançların kendi içerisinde şiddet kullanmanın meşruluğu ve gerekliliğinin tanımlanmasıyla gelişir. Radikalleşme süreci, şiddet araçlarının kullanımının meșru kabul edilerek sistematik hâlde kullanılmaya başlaması ile terörizme dönüşür. $\mathrm{Bu}$ safhada şiddet, radikal amaç ve hedeflere ulaşmak için araç olarak kullanılmasının yanında, terörist eylem ve faaliyetlere katılanların grup dinamiklerine

\footnotetext{
${ }^{70}$ Alex P. Schmid, a.g.e., s. 9.

${ }^{71}$ A.g.e., s. 9.
} 
bağlı olarak da gelişmeye başlar. Nihayetinde düşünsel olarak belirli amaçlara ulaşmak için başlayan radikalleşme süreci, etki-tepki mekanizması içinde şekillenen ve şiddeti araç olarak kullanmayı benimseyen bir terörist harekete dönüşür.

Radikalleşme sürecinde şiddetin sistematik olarak araçsallaştırıldığı noktada ortaya çıkan terörist örgütlerin, sadece örgüt içinde aktif olarak faaliyet gösteren kişilerden oluşan bir grup olarak ele alınması yetersizdir. ${ }^{72} \mathrm{Bu}$ anlamda, tarihsel süreçte hemen hemen tüm terörist hareketler, arka planda destekleyici bir çevre ile başlica hedef kitlesi içinden belirli bir taraftar kitlesiyle birlikte ortaya çıkmıştır. 1870'lerde modern terörizmin ortaya çıkmasından itibaren, ister şiddet içeren eylemler olsun, ister şiddet içermeyen aktivizm olsun, her terörist grup istisnasız olarak daha geniş toplumsal, politik veya etnik tartışmalara ilişkin koşulları ve yoksunlukları refere etmiştir. $^{73}$

Radikalleşme sürecini destekleyen başka bir unsur da bilgi teknolojilerindeki hılı gelişmelerdir. Günümüz bilgi teknolojileri radikal düşüncelere sahip insanların, benzer düşüncelere sahip dünyanın herhangi bir yerindeki diğer insanlarla kolaylıkla ve hızlı bir şekilde bağlantı kurup örgütlenebilmesine olanak sağlamaktadır. DEAŞ'ta ${ }^{74}$ görüldüğü gibi, internet vasıtasıyla dünyanın birçok yerinden binlerce kişinin örgüte katılabilmesi ve örgütün ideolojik fikirlerini yayabilmesi radikalleşmenin "kar topu" etkisine örnek olarak verilebilir. ${ }^{75}$

\footnotetext{
${ }^{72}$ Rex A. Hudson, The Sociology and Psychology of Terrorism: Who Becomes A Terrorist and Why?, A Report Prepared Under an Interagency Agreement by the Federal Research Division, Library of Congress, Ekim 1999, s. 12.

${ }^{73}$ Mark Sedgwick, a.g.e,. s. 485.

${ }^{74}$ Arapça “ad Davla al-İslamiya fill- 'Irak ve eş-Şam” teriminin kısaltmasıdır.

${ }^{75}$ Mustafa Aydın, "The Connection Between Radicalism, Extremism and Terrorism", 31 December 2015, http://www.hurriyetdailynews.com/the-connection-between-radicalismextremism-andterrorism.aspx?PageID $=238 \& N I D=93231 \&$ NewsCatID $=468 \quad$ (Erişim Tarihi: 03.03.2017). Suriye ve Irak'taki çatışmalarda DEAŞ'a katılan 25.000-30.000 civarında yabancı terörist savaşçıdan 4.000-5.000'inin Batı ülkelerinden geldiği tahmin edilmektedir. Bkz. Mustafa Aydın, a.g.e.
} 
Bir terörist grup, amaçlarını meşru kabul eden ancak terörizmin

Güvenlik Stratejileri

Y11: 14

Sayı: 28 ayırt edici özelliği olan sivillere yönelik saldırıları onaylamayan toplum tabanının sadece belirli bir kısmını temsil eder. ${ }^{76} \mathrm{Bu}$ kapsamda, terörist hareketlerin arka planı dikkate alındığında, doğrudan silahlı eylemlerde yer alan teröristler, teröristleri destekleyenler ve terörist harekete sempatiyle bakanlar olmak üzere üç seviyede ele alınabilir ${ }^{77}$ (Şekil-2). Terörist örgütlerin içinde aktif olarak faaliyette bulunan elemanlar örgütlerin amaçlarına çok daha bağlı ve radikaldir; gerektiğinde örgütün amaçları uğruna hayatlarını feda etmekten kaçınmaz. ${ }^{78}$ Teröristler ile temsil ettikleri kitlelerin tabanında yer alan sempatizanlar arasındaki en önemli fark, teröristlerin inançlar, duygular ve davranışlar açısından çok daha radikal olmalarıdır. ${ }^{79}$

${ }^{76}$ Clark McCauley, "War Versus Justice in Response to Terrorist Attacks: Competing Frames and Their Imlications", Bruce Bongar vd. (Eds.), Psychology of Terrorism, Oxford University Press, New York, 2007a, 56-65, s. 62.

${ }^{77}$ Muro'nun geliştirdiği politik radikalleşmenin piramid modelinde (Pyramid Model of Political Radicalisation), radikalleşme seviyeleri radikal, aktivist, destekçi ve sempatizan şeklinde tasnif edilmiştir. Bu şekilde bir tasnifte teröristlik seviyesi radikal olarak ifade edilmiş; aktivistlik ile destekçi seviyeleri arasındaki ayrım net olarak ortaya konulamamıştır. Radikalizmin kavramsal incelemesinde bütün radikallerin şiddeti benimsemediği ve terörizme yönelmediği ortaya konulmuştur. Bu nedenle, bu çalışmada terörist, destekçi ve sempatizan şeklinde yeni bir tasnif yapılmıştır. Bkz. Diego Muro, a.g.e., s. 4.

${ }^{78}$ Mehmet Kurum, Terörist Örgütlerin Güvenli Ortamları ve PKK, Nobel Akademik Yayıncilık, Ankara, 2017, s. 67.

${ }^{79}$ Clark McCauley ve Sophia Moskalenko, "Mechanisms of Political Radicalization: Pathways Toward Terrorism", Terrorism and Political Violence, 2008, Cilt: 20, No. 3, 415-433, ss. 416-417. 
Şekil-2: Terörizme Desteğin Seviyeleri.

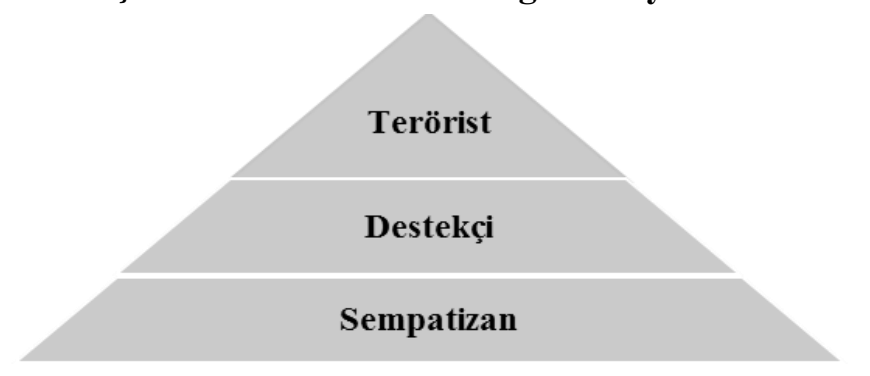

Fiziki olarak geniş ve dağınık bir alanda faaliyet gösteren teröristlerin, örgütlerine ve birbirlerine olan güçlü bağlılığı ancak grup içindeki ideolojik amaçların önemi ve gücü ile açıklanabilir. ${ }^{80}$ Örneğin 11 Eylül saldırlarını gerçekleştiren teröristler, farklı yerlerde konuşlanmalarına rağmen örgütün amaçları için hayatlarını feda etmekten kaçınmamıştır. Destekçiler ise, örgütlerin amaç ve hedeflerine bağlı olmakla birlikte, fonksiyonları gereği hayatlarını feda etme konusunda aktif elemanlar kadar bağl1lı göstermeyebilir. Terörist örgütlerin yap1 ve faaliyet alanlarına göre destekçiler, daha çok yasal zeminde faaliyet gösterir. Fakat ihtiyaç olduğunda yasa dış1 eylem ya da faaliyetlerde de bulunabilirler. Üçüncü seviye olan sempatizanların güdülenmeleri, aktif elemanlara göre çok daha zayıftır. Bu nedenle, sempatizanların grup faaliyetlerine katılmaları sınırlıdır. ${ }^{81}$ Eğer sempatizanların güdüleri doğru yönlendirilemezse, örgüte bağl1lıkları zaman içerisinde azalır ve sadece temsili boyutta kalır. ${ }^{82}$ Terörist örgütlerin temsil ettiklerini iddia ettikleri toplum tabanının bir kısmı, acımasız terör eylemlerini

\footnotetext{
${ }^{80}$ Clark McCauley, "Psychological Issues in Understanding Terrorism and the Response to Terrorism", Bruce Bongar vd. (Eds.), Psychology of Terrorism, Oxford University Press, New York, 2007, 13-31, ss. 19-21.

${ }^{81}$ Mehmet Kurum, a.g.e., s. 67.

${ }^{82}$ Martha Crenshaw, "Theories of Terrorism: Instrumental and Organizational Approaches", David Rapoport (Ed.), Inside Terrorist Organizations, Frank Cass Publishers, Londra, 2001, 13-31, s. 26.
} 
$62 \mid$ onaylamasa da genel anlamda terörist örgütü destekleyebilmektedirler. ${ }^{83}$

Güvenlik Stratejileri

Y11: 14

Say1: 28 $\mathrm{Bu}$ şekilde, terörist örgütler, zaman içinde tabanın aktif desteğini artırmak amacıyla terör faaliyetlerinin destekçilerin yararına, hatta onlar adına yapıldığg şeklinde algılanması için çaba sarf eder ${ }^{84}$ Terörist örgütlerin devamlılıklarını sağlaması, örgüt içinde aktif olarak faaliyet gösteren elemanlarının yanında kendi amaçlarını sürekli destekleyen ve sempati duyan bir kitlenin olmasıyla yakından ilişkilidir. ${ }^{85}$

\section{Şekil-3: Terörizme giden basamaklar. ${ }^{86}$}

\section{Terörist eylemler}

\section{Terörist örgütün} meşru algılanması

\section{Manevi ve ahlaki bağllık}

2. Saldırganlğın yer değiştirmesi

\section{Haksız muameleye karşı mücadele}

\section{Zemin: Maddi koşulların psikolojik yorumu}

${ }^{83}$ John Horgan, "The Social and Psychological Characteristics of Terrorism and Terrorists", Tore Bjorgo (Ed.), Root Causes of Terrorism: Myths, Reality and Ways Forward, Routledge, Londra, 2005, 44-53, s. 51.

${ }^{84}$ Scott Gerwehr ve Kirk Hubbard, "What Is Terrorism: Key Elements and History", Bruce Bongar vd. (Eds.), Psychology of Terrorism, Oxford University Press, New York, 2007, 87-100, s. 92.

${ }^{85}$ Mehmet Kurum, a.g.e., s. 68.

${ }^{86}$ Fathali Moghaddam, "The Staircase to Terrorism", American Psychologist, Vol: 60, No. 2, 2005, 161-169, s. 161. 
Bu noktada, şiddet içeren aşırıcıllı̆g ve terörizme giden radikalleşme sürecinin nasıl gerçekleştiğinin ve şiddetin nasıl araçsallaştırıldığının ortaya konulmas1 gerekmektedir. Moghaddam'ın “Terörizme Giden Basamaklar" (Şekil-3) yaklaşımında terörist faaliyetlere giden radikalleşme süreci aşamalar hâlinde ele alınmıştır. Terörizme giden basamağın ilki olan zeminde, maddi koşulların psikolojik yorumuna bağlı olarak adaletsizlik algısı ve hayal kırıklığı duygusu hâkimdir. Burada maddi koşulların psikolojik yorumu sübjektiftir; zaman ve zemine göre değişebilir. Zeminde milyonlarca insanın haksızlığı algılayıp nispeten yoksun hissettiği koşullarda, hoşnutsuz nüfusun bir kısmı çözüm bulmak için birinci basamak olan "haksız muameleye karşı mücadele seçeneklerinin algılanması" basamağına geçiş yapabilir. Burada durumlarını iyileştirmenin ve daha fazla adalete ulaşmanın yollarını araştırırlar. Fakat bu seviyede bireysel olarak çözüm olasılıklarını görmezler ve kararların alındığı prosedürleri yeterince etkileyebileceklerini düşünmezler ise bir üst basamak olan "saldırganlığın yer değiştirmesi" basamağına geçiş yapabilirler. Bu basamakta saldırganlık düşman olarak tanımlanan hedeflere fikirsel ve düşünsel olarak yönelmeye başlar. Ayrıca, ağır adaletsizlik algısına sahip kişiler öfke ve hayal kırıklığı yaşar. Bu kişilerin saldırganlıkları bazı durumlarda liderlerin de etkisiyle belirli bir düşmana yönelir. Saldırganlıklarını fiziksel olarak düşmanlarına yöneltme eğiliminde olanlar, bir üst basamak olan "manevi ve ahlaki bağl1lık" basamağına çıkar ve örgütün değerlerini benimsemeye başlar. Bu kişiler artık terörizmi haklı ve meşru bir strateji olarak görür. Terörist örgütün ahlakıyla daha fazla meşgul olanlar aktif terörist olarak örgüte katılmaya hazır hâle gelir. Dördüncü basamakta, artık kişiler terörist örgüte katılmış, "bize karşı onlar" kategorik algısı keskinleşmiş ve terörist örgüt meşru görülmeye başlanmıştır. Son basamakta, terörist örgüte katılan kişiler, başkalarına ve kendilerine zarar vermeyi engelleyecek yasaklayıcı ve önleyici mekanizmalardan kaçınacak şekilde eğitilir ve terörist eylem yapmak üzere görevlendirilir. ${ }^{87}$

\footnotetext{
${ }^{87}$ Fathali Moghaddam, a.g.e., ss. 161-162.
} 
Güvenlik

Stratejileri

Y11: 14

Say1: 28

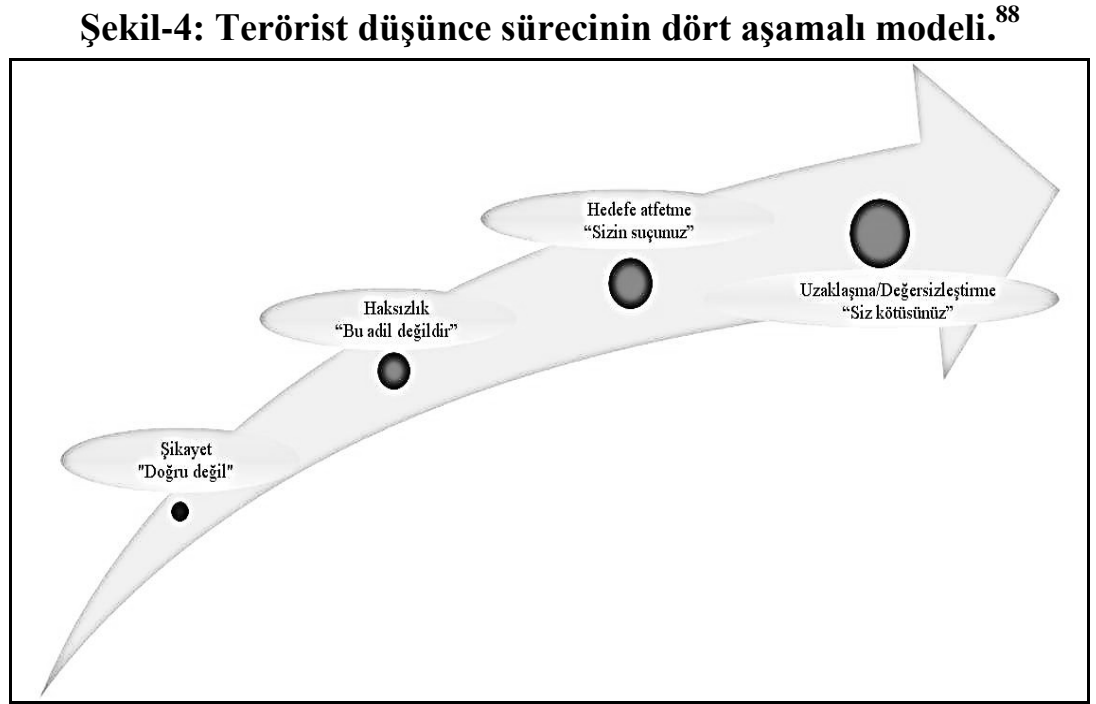

Benzer şekilde, Borum, "terörist düşünce sürecinin" nasıl geliştiğini açıkladı̆̆1 "Dört Aşamalı Modeli"nde (The Four-Stage Model), farkl1 ideolojik altyapılara sahip şiddeti araç olarak kullanmayı benimseyen çeşitli grupların radikalleşme süreçlerinin ortak temel özelliklerini ortaya koymuştur. $\mathrm{Bu}$ modelde haksızlıklar ve mağduriyetler ile hassasiyetlerin nasıl başka gruba karşı nefrete dönüştüğü ve söz konusu nefretin bir kısmının şiddeti nasıl meşrulaştırıldığı veya itici güç hâline getirildiği açıklanmaya çalışılmıştır. Dört aşamalı model (Şekil-4) tatmin edici olmayan bir olay, durum ya da şikâyetin ilk aşamada "doğru değil" olarak tanımlanması ve bu durumun adaletsizliğe neden olması sonrasındaki ikinci aşamada "bu adil değildir" şeklinde kabul edilmesini ihtiva eder. Üçüncü aşamada ("sizin suçunuz"), adaletsizlik durumu bir politikaya, kişiye ya da ulusa atfedilir. Dördüncü ve son aşamada, sorumlu olarak kabul edilenler "siz kötüsünüz"

${ }^{88}$ Randy Borum, a.g.e., s. 39. 
şeklinde nitelendirilerek ve hatta şeytanlaştırılarak, saldırganlığın meşrulaştırılması veya bir güdü hâline getirilmesi kolaylaştırılmış olur. ${ }^{89}$ Söz konusu modelde, göreli yoksunluk ve haksızlığa uğradığı inancıyla ortaya çıkan, ahlaki olarak tanımlanan kin ve öfkenin nasıl sözde adaletsizlik algısı ile terörist eylemlerin meşrulaştırıldığı ortaya konulmuştur. ${ }^{90}$ Moghaddam ile Borum'un yaklaşım ve modellerinde terörizme giden zihniyetin başlangıç noktası temelde haksızlıklar ve mağduriyetler ile hassasiyetler olarak ele alınmıştır. Böylece, sadece mağduriyetler veya haksızlıklar değil, yeni bir devlet kurma, mevcut iktidarı ele geçirme, kendi ideolojisini yayma, ayrılıkçılık gibi idealize edilmiş amaç ve hedeflerden oluşun farklı olgular da terörizme giden yolun başlangıç noktalarını oluşturabilir.

Terörizme giden radikalleşme ve aşırıcılık süreci, öncelikle bireylerin bir konuda haksızlığa uğradığı inancı veya idealize edilmiş amaç ve hedefler ile başlamaktadır. Daha sonra haksızlığın kaynağı veya sorumlusu olarak kabul edilen kişiler, gruplar, toplumlar ya da devletler düşman olarak tanımlanarak şiddetin meşru hedefi hâline getirilebilmektedir. Radikal hareketlere ilişkin yapılan birçok araştırmada, bireyleri ve grupları radikal ortama ve şiddet içeren aşırıcılığa yönelten tek bir sebep olmadığı, aksine birçok karmaşık çekici ve itici iç ve dış faktör ile tetikleyici etmenin olduğu görülmektedir. ${ }^{91}$ Radikalleşme süreçlerini anlamak için, bir taraftan bireyleri ve hareketleri siyasal şiddete yönelten temel şikâyetlerin, şiddet eğilimli ideolojilerin, saldırgan dürtüler ile motivasyonların neler olduğuyla ilgilenilirken, diğer taraftan söz konusu etkenlerin hangi çevresel uyaranlar ve koşullar tarafından tetiklendikleri üzerine odaklanılmıştır. $\mathrm{Bu}$ anlamda bireyler ve gruplar, şiddetin kullanımını tolere eden veya meşru gösteren ideolojileri veya amaçları benimsemiş, derin yoksunluk algısını tecrübe etmiş veya çevresel uyaranlara maruz kalmış ise ideoloji, amaç ve grup içi/dış1

\footnotetext{
${ }^{89}$ Randy Borum, a.g.e., ss. 38-39.

${ }^{90}$ Diego Muro, a.g.e., s. 3.

${ }^{91}$ Alex P. Schmid, a.g.e., s. 9.
} 
66

Güvenlik

Stratejileri

Y11: 14

Say1: 28

dinamiklerin etkileriyle şiddeti araçsallaştırarak büyük oranda terörizme yönelebilir. ${ }^{92} \mathrm{Bu}$ süreç Şekil-5'teki gibi özetlenebilir. Takip eden alt başl1klarda irdeleneceği üzere, radikal hareketlerin nasıl ve hangi şartlarda şiddete yönelerek araçsallaştırıldığının ortaya konulması, bu denklemin en önemli kısmını teşkil eder.

\section{Şekil-5: Radikal Hareketlerin Terörizme Dönüşüm Süreci.}

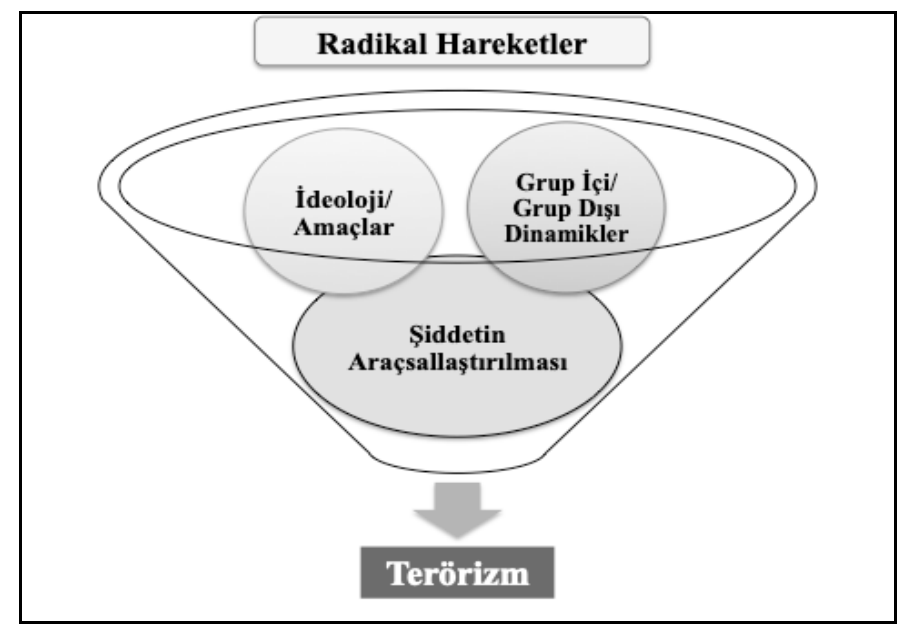

\section{1 Şiddetin Araçsallaştırılması}

Teröristler, istedikleri siyasal değişikliklerin gerçekleştirilmesini sağlamak amacıyla şiddet eylemlerini zorlayıcı bir araç olarak gerçekleştirir. Bunun yanında, siyasete dair hoşnutsuzluklarına dikkat çekmek içinde şiddet kullanmayı seçebilirler. $\mathrm{Bu}$ anlamda terörizm; kişileri siyasal muhalefete yönelten sorunlar ile sorunların çözümü için şiddetin tercih edildiği radikalleşme sürecinin birleşiminden oluşan iki

${ }^{92}$ Eitan Y. Alimi vd., The Dynamics of Radicalization: A Relational and Comparative Perspective, Oxford University Press, Oxford, 2015, ss. 7-8. 
taraflı bir durum olarak ortaya çıkar. Radikalleşme, şiddete ve köktenci ideolojilere eğilimli gruplar için örgütsel kaynakların yaratıldığı uzun bir süreçtir. $\mathrm{Bu}$ dönüşüm süreciyle bireyler ve gruplar, artan bir biçimde siyasi amaçlarına ulaşmak için şiddet araçlarını kullanmaya başlayabilir. Bunun yanında, daha önce barışçıl olan muhalif grupların terörizme başvurmaya karar verme süreçleri, hem dış baskılara, hem de grup üyeleri arasındaki etkileşimlere tepki olarak grubun içinde bulunduğu sosyal gerçeklik içerisinde gelişir. ${ }^{93}$

Radikal hareketlerde siyasi amaçlara ulaşmak için şiddetin araç olarak meşru kabul edilmesi ve benimsenmesinde iki mekanizma ortaya çıkmaktadır. Bunlardan ilki, amaçlar ile bu amaçlara ulaşmak için kullanılan ideolojik altyapının şiddetin kullanılmasını meşrulaştırıcı söylemleri içermesi, diğeri ise radikal hareketlerin grup içi ve grup dış1 etkileşimleridir. Radikalleşme, bireysel bir süreç olduğu kadar sosyal bir süreçtir. Bunun nedeni, kolektif eylemlerin, kökünde siyasi amaçlar için birlikte hareket eden bir grup birey ile ilgili olmasıdır. Bu nedenle, radikalleşme süreçlerinin anlaşılması grup dinamiklerinin anlaşılmasıyla yakından ilişkilidir. ${ }^{94}$ Terörizme giden süreç, benzer fikir, düşünce ve duygulara sahip bir insan grubunun ortak amaçlar etrafında bir araya gelmesi ile başlar. Nihayetinde geniş bir grubun parçası olarak ortaya çıkan terörist örgütler, temelde haksızlık duygusunu örgüt kapsamında özelleştiren, amaç ve hedefler ile nihai idealleri belirleyen ve düşmanı tanımlayan ideoloji ile grup dinamikleri etrafında şekillenir. ${ }^{95}$

Radikalleşme ve radikalleşmenin azaltılmasına yönelik yaklaşımının üç önemli unsuru olduğunu öne süren Kruglanski vd., söz konusu unsurları; (1) ulaşılması gereken hedefi tanımlayan motivasyon unsuru (bireyin önem arayış1), (2) amaçları gerçekleştirmek için uygun şiddet araçlarını tanımlayan ideolojik unsur ve (3) bireylerin şiddeti meşru gösteren paylaştıkları ideolojileri ve

\footnotetext{
${ }^{93}$ Eteri Tsintsadze-Maass ve Richard W. Maass, a.g.e., s. 736.

${ }^{94}$ Colin J. Beck, a.g.e., s. 68.

${ }^{95}$ Mehmet Kurum, a.g.e., s. 65.
} 
68

Güvenlik

Stratejileri

Y11: 14

Say1: 28

bunları önem kazanma aracı olarak uygulamaya koydukları örgütlenme ve grup dinamiklerinin oluşturduğu sosyal süreçler olarak ifade

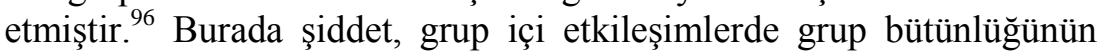
sağlanmasında, grup dışında ise gerçekleştirilen eylem ve faaliyetlere karşı düşman olarak tanımlanan aktörler tarafından şiddet ile karş1lık verilmesi durumunda tepkisel anlamda meşru araç olarak görülmeye başlamasında ortaya çıkar. Bu noktada, artık terörist hareket içerisinde radikalleşme ve aşırıcıllğga dönüşüm süreci, sadece düşünceler etrafında değil, aynı zamanda eylem ve faaliyetlerin şekillendiği ve şiddetin araçsallaştırıldığı grup içi ve dışı dinamikleri içinde gelişmeye başlar.

\section{2. Şiddetin Araçsallaştırılmasında İdeolojinin Rolü}

İdeoloji, bir kişi veya grubun politik ve sosyal planlara, faaliyetlere veya sistemlere dönüştüğü düşünceleri karakterize eden fikir, doktrin ve inançlar bütünü olarak tanımlanabilir. ${ }^{97}$ Bir ideoloji, bir grubun ayırt edici siyasi kimliğini ve amaçlarını tanımladığı inançlar, değerler, ilkeler ve hedeflerden oluşur. Bazı ideolojiler özellikle ayrılıkçı ve politize edilmiş dinî unsurlar içerirken, bazıları tarihî, yarı efsanevi ve doğaüstü inanç unsurlarını içerebilir. Burada önemli olan ideolojinin eylem için bir neden ve çerçeve oluşturmasıdır. ${ }^{98}$ Terörist örgütlerin amaç ve gündemlerinin formüle edildiği ideolojileri, haklarını savunduklarını iddia ettikleri etnik veya dinî toplumlar ile sosyal grup veya sınıfların belirli kesimleri üzerinde çok önemli etkiye sahiptir. Bu anlamda ideoloji, sadece dünya görüşü oluşturan bir düşünme şekli değil, aynı zamanda bireyler ve grupların haksızlık ve deneyimlerinin sosyopolitik eyleme dönüşmesini söylemler ve araçlar ile destekleyen

${ }^{96}$ Arie W. Kruglanski vd., "The Psychology of Radicalization and Deradicalization: How Significance Quest Impacts Violent Extremism", Advances in Political Psychology, 2014, Cilt: 35, No. 1, 69-93, s. 69.

${ }^{97}$ Ekaterina Stepanova, Terrorism in Asymmetrical Conflict: Ideological and Structural Aspects, SIPRI Research Report No.23, Oxford University Press, New York, 2008, s. 21.

${ }^{98}$ C. J. M. Drake, "The Role of Ideology in Terrorists' Target Selection", Terrorism and Political Violence, 1998, Cilt: 10, No. 2, 53-85, ss. 54-55. 
temel unsur olarak ortaya çıkar. ${ }^{99}$

Daha çok terörizm ile yakından ilişkili olarak ön plana çıkmış olsalar da, ideolojilerin hepsi şiddet yanlısı değildir. Bu anlamda bazı ideolojiler, pozitif ve toplum yanlısı, toleranslı ve empatik davranışları onaylayıcı olabilmektedir. Bir başka ifadeyle bir davranışın toplum yararına ya da toplum karşıtı olarak kabul edilip edilmemesi ideoloji tarafından tanımlanmış olan anlamlara bağlıdır. ${ }^{100}$ İdeolojiler, mevcut veya sorun olarak algilanan problemlerin çözümleri ile yaklaşımlarına ilişkin bütün politik görüşleri içerir ve grupların şiddete başvurmalarının ancak onların inançlarının yeterince güçlü ve mevcut haksızlığı açıklayan gelişmiş bir politik ideoloji tarafından desteklenmesi ile gerçekleşir. ${ }^{101}$ $\mathrm{Bu}$ noktada şiddeti araç olarak benimseyen ve benimsemeyen ideolojiler arasında ayrım yapılması gerekmektedir. ${ }^{102}$ Dinî konulardan çevrecilik ve milliyetçilik konularına kadar çeşitli ideolojiler tarafından davranışları şekillenen gruplar, şiddeti farklı şekillerde kullanır. Bazı gruplar kişilere fiziksel olarak zarar vermeden sadece yapılara ve finansal sistemlere zarar veren taktikleri kullanırken, El Kaide gibi gruplar hedef gözetmeksizin ölümlere yol açan intihar saldırıları gibi yöntemleri kullanabilmektedir. ${ }^{103}$

Radikal hareketler içerisinde amaçlara ulaşmak için şiddetin araç olarak benimsenip benimsenmemesi, hareketlerin yönlendirildiği ve haksızlık algısının özelleştirildiği grupların benimsedikleri ideolojileri etrafında gelişir. Bir davranışın oluşmasında sadece amaçların etkinleştirilmesi tek başına yeterli değildir. Amaçlara ulaşmak için kullanılacak araçların da tanımlanması gerekmektedir. Bireylere ne

\footnotetext{
${ }^{99}$ Ekaterina Stepanova, a.g.e., s. 21.

${ }^{100}$ Arie W. Kruglanski vd., ss. 78-79.

${ }^{101}$ James M. Lutz, ve Brenda J. Lutz, Global Terrorism, (2. Baskı), Routledge, Londra, 2008, s. 130.

${ }^{102}$ Diego Muro, a.g.e., s. 2.

${ }^{103}$ Katharine A. Boyd, "Group-level Predictors of Politicial and Religiously Motivated Violence", Gary LaFree ve Joshua Freilich (Eds.), The Handbook of the Criminology of Terrorism, Wiley Blackwell, West Sussex, 2017, 77-92, s. 77.
} 
70

Güvenlik

Stratejileri

Y11: 14

Sayı: 28

yapılması gerektiğini söyleyen terörizmi meşrulaştıran bir ideoloji, aynı zamanda amaçlara ulaşmak için kullanılması gereken araçların da ne olmas1 gerektiğini söyleyecektir. Grup üyelerinin kolektif inanç sistemini oluşturan ideolojileri tarafindan grubun (gerçek veya hayali anlamda), tehdit altında olduğu işaret edildiğinde, kendilerini savunmalarının en önemli görevleri olduğu, en kutsal değerlerinin grubun varlığını devam ettirmek ve değerlerini korumak için muhtemel bütün araçların kullanılmasının grup üyelerinin en büyük sorumluluklarından biri olduğu dikte edilir. $\mathrm{Bu}$ anlamda terörizmi meşrulaştıran ideolojiler, radikalleşme sürecinde amaçlara ulaşmak için hangi şiddet ve terörizm araçlarının kullanılacağının belirlenmesinde merkezî rol oynar. ${ }^{104}$ Bunun yanında, bir terörist grubun ideolojisi, hangi insanların ve kuruluşların masum ya da suçlu olup olmadığının belirlenmesi açısından bir ölçüt olarak kimin düşman, kimin dost olduğunun tanımlanmasında yönlendirici bir fonksiyon olarak ortaya çıkar. ${ }^{105} \mathrm{Bu}$ şekilde ideoloji kimin veya neyin meşru bir hedef olabileceğini tasvir eder. ${ }^{106}$

Şiddeti araç olarak benimseyen ideolojiler üç unsuru içerir. İlki gruba karşı yapılan haksızlığın, ikincisi de haksızlığa neden olan oluşum veya suçlunun tanımlanmasıdır. Söz konusu haksızlık bazen bir düşman tarafından doğrudan gerçekleştirilen eylemler sonucu ortaya çıkabilirken, bazen de haksızlık durumu ile ilgili başkasını suçlama süreci sonucunda bir oluşumun sorumlu tutulması şeklinde gerçekleşebilir. Burada genelde temel kolektif ihtiyaçların karşılanamadığı ekonomik zorluklar, açlık veya salgın hastalıkların yaşandığı zamanlarda ortaya çıkar. Bu yaşanan zorlukların suçluları olarak grup dışındaki oluşumlar gösterilir. Üçüncü unsur, haksızlıktan sorumlu tutulan kişi veya oluşumlara karşı şiddetin kullanılmasının meşru bir zorunluluk olarak tanımlanmasıdır. Bu durumda ideolojiler, ahlaksız ve değersiz olarak kabul edilen diğer kişilere karş1 şiddet

\footnotetext{
${ }^{104}$ Arie W. Kruglanski vd., a.g.e., s. 76.

${ }^{105}$ C. J. M. Drake, a.g.e., s. 56.

${ }^{106}$ Katharine A. Boyd, a.g.e., s. 83.
} 
kullanılmasını ve onlara zarar verilmesini meşru eylemler olarak kabul eder. Hatta bu şekilde ideolojiler, örneğin "münafik" olarak nitelendirilen kişilerin bulunduğu bir otobüse düzenlenen intihar saldırısında olduğu gibi, bazı şiddet eylemlerini sadece hoşgörmekle kalmaz, aynı zamanda bunun bir zorunluluk ve takdir edilmesi gereken bir eylem olduğu şeklinde meşrulaştırarak taraftarlarını destekleyici bir araç olarak tanımlar. Bunun yanında, kendi grupları dışında hedef aldıkları kişi veya grupları, insanlık dışı yaratıklar ve topluma yıkıcı bir şekilde zarar verenler (katiller, hırsızlar, psikopatlar) olarak nitelendirerek kendileri tarafından gerçekleştirilen ahlak dış1 eylemlerini meşrulaştırabilir. ${ }^{107}$

Çeşitli terör biçimleriyle ilgili radikalleşme sürecinde ortak bir özellik olarak ortaya çıkan ideoloji, mevcut sosyo-politik durumdan memnun olmayan küçük ancak önemli bir azınlığın radikalleşmesinde belirgin bir faktör oluşturur. $\mathrm{Bu}$ da, şiddet içeren düşüncelerin ve tutumların güçlenmesine katkıda bulunarak bir şiddet alt kültürü oluşmasını sağlar. Bunun yanında ideoloji, potansiyel olarak şiddetin kullanılmasını önleyici ahlaki mekanizmaları azaltmak ve intihar saldırıları ile ayrım gözetmeyen yüksek zayiata neden olan saldırıların meşru görülmesinde kullanılır. Şiddet eylemleri repertuarında aşırı uç taktikler ile elde edilebilecek stratejik faydalar göz önüne alındığında, ideoloji aynı zamanda eylemleri rasyonel bir bakış açısı ile meşru ve haklı çıkarmak için bir çerçeve sunabilir. ${ }^{108}$ Radikalleşmeye giden süreçte motivasyon, grubun kolektif ideolojisi tarafindan tanımlanan haksızlık veya grubun önem kaybının yeniden şekillendirilmesiyle sağlanır. Eğer söz konusu ideoloji, terörizmi meşru ve haklı bir araç olarak tanımlarsa, bireyler terörizmi destekleyerek benimseyebilir. ${ }^{109}$ $\mathrm{Bu}$ anlamda terörizmi meşrulaştıran ideoloji, gruplarının aleyhinde

${ }^{107}$ David Webber ve Arie W. Kruglanski, "Psychological Factors in Radicalization: A '3N' Approach", Gary LaFree ve Joshua Freilich (Eds.), The Handbook of the Criminology of Terrorism, Wiley Blackwell, West Sussex, 2017, 33-46, ss. 40-41. ${ }^{108}$ European Commission's Expert Group on Violent Radicalisation, a.g.e., s. 14.

${ }^{109}$ Arie W. Kruglanski vd., a.g.e., s. 80. 

savunan ve bu şekilde şiddetin kullanılmasının hem etkili, hem de

Stratejileri

Y11: 14

Sayı: 28 kendi toplumlarına üst seviyede katkı sağlayan ahlaki olarak takdir edilmesi gereken bir davranış olarak kabul eden önemli bir inanç sistemi oluşturur. Bu kapsamda, terörizm ile şiddet içeren inanç sistemi olarak ideoloji başkalarının gözünde değer kazanır ve bu da eylemleri gerçekleştiren kişilerin tatminkâr hissetmesini sağlar. ${ }^{110}$

Grupların benimsedikleri ideolojilere göre şiddeti meşrulaştırma ve kullanma taktikleri farklılaşmaktadır. Genel olarak gruplar benimsedikleri ideolojilere göre; solcu, sağc1, etnik milliyetçi/ayrılıkçı ve dinî veya kutsal örgütler olmak üzere kategorize edilebilir. ${ }^{111}$ Grupların benimsedikleri ideolojilerinin farklı olması, şiddetin ideolojik çerçevede araçsallaştırılmasında da farklılıklara yol açar. Çeşitli grupların ideolojileri ile kullandıkları şiddet arasındaki ilişkileri inceleyen Boyd, nefretten esinlenen veya hükûmet karşıtı dini referans alan aşırı sağ grupların, dini referans almayan nefret gruplarına göre şiddet kullanma eğilimlerinin daha az olduğunu; hırslı ve önyargılı grupların ise şiddete daha fazla başvurma eğiliminde olduğunu ifade etmiştir. Ayrıca hükûmet karşıtı grupların dini referans almayan önyargılı gruplara göre yasal politik faaliyetlere katılma eğilimi daha fazla iken, dini referans alan önyargilı grupların yasal politik faaliyetlere katılma eğilimi çok daha düşük olduğu sonucuna varmıştır.

\footnotetext{
${ }^{110}$ Arie W. Kruglanski vd., a.g.e., s. 78.

${ }^{111}$ Audrey Kurth Cronin, "Behind the Curve: Globalization and International Terrorism", Michael E. Brown vd. (Eds.), Contending with Terrorism: Roots, Straegies, and Responses, The MIT Press, Londra, 2010, 28-56, s. 37. Bu noktada birçok terörist örgütün motivasyon kaynaklarının farklı ideolojilerin karışımından oluştuğunu belirtmek gerekmektedir. Bkz. Audrey Kurth Cronin, a.g.e., s. 37. Benzer şekilde, aşağıdan yukarıya terörizmi motivasyonlarına göre ideolojik terörizm (sol ve sağ), etnik milliyetçi/ayrılıkçı terörizm ve dinî motivasyonlu terörizm olarak üç kategoride ele alan Demir, bu şekildeki bir sınıflandırmanın çok keskin ve net olamayacağına işaret etmiş ve ideolojik motivasyonlu bir terörist örgütün dinî değerleri kullanabildiğini ya da etnik milliyetçi/ayrılıkçı bir terörist örgütün ideolojilerini amaçları kapsamında yorumlayabildiğini ifade etmiştir. Bkz. Cenker Korhan Demir, Sebeplerinden Mücadele Yöntemlerine Avrupa'da Etnik Ayrılıkçı Terörizmin Analizi: PIRA, ETA, PKK, Nobel Akademik Yayınc1lı, Ankara, 2017, s. 98.
} 
$\mathrm{Bu}$ kapsamda, grupların ideolojileri ve ideolojilerini desteklemek için kullandığı çeşitli araçların grupların şiddeti kullanıp kullanmamaları üzerinde farklı etkileri olabilmektedir. ${ }^{12}$ Bunun yanında ideolojiler, grupların üyelerine öldürme eylemleri gerçekleştirebilecekleri konusunda yönlendirmede önemli rol oynarlar. ${ }^{113} \mathrm{Bu}$ nedenle, dini referans alan etnik milliyetçi gruplar ile sadece dini referans alan gruplar çok daha öldürücü eylemler gerçekleştirebilir. Benzer şekilde, dini referans alan ideolojiler, intihar saldırılarını bir saldırı taktiği olarak hem amaçsal, hem de zorunluluk olarak dini referanslar ile destekleyebilmeleri nedeniyle taktik olarak çok daha sık kullanma eğiliminde olmuştur. $\mathrm{Bu}$ anlamda, dini referans alan ideolojileri benimseyen grupların belirli bir amaç için kendi hayatlarını feda etme konusunda cesaret ve isteklerinin diğer gruplara oranla çok daha fazla olduğu gözlenmiştir. ${ }^{114}$

\section{3. Şiddetin Araçsallaștırılmasında Grup Dinamikleri}

Radikalleşme sürecinde şiddetin meşru bir araç olarak benimsenmesi ve kullanılması, grup ideolojilerinin yanında kişilerin bulundukları grupların iç ve diş dinamiklerinin etkisiyle de gelişir. Nitekim belirli bir ideolojinin benimsenmesi, radikalleşme sürecinin gerçekleşeceğini garanti etmediği gibi şiddetin araç olarak kullanılmasını da garanti edemez. Kişinin şiddet içeren radikalleşmeye kişisel ve toplumsal olarak doğrudan geçiş yapabilmesi için diğer pek çok unsurun karşılıklı etkileşim içinde olması gerekmektedir. Bu çerçevede yapılan bazı çalışmalarda, ideolojinin radikalleşme süreçleriyle değişen derecelerde ilişkili olduğu açıkça ortaya konulmuştur. ${ }^{115} \mathrm{Bu}$ anlamda, belirli bir nüfus içinde tanımlanabilir bir kesim veya azınlık içerisinde ortaya çıkan şikâyet ve

\footnotetext{
${ }^{112}$ Katharine A. Boyd, a.g.e., s. 83.

${ }^{113}$ Alex P. Schmid, a.g.e., s. 28.

${ }^{114}$ Katharine A. Boyd, a.g.e., ss. 84-85.

${ }^{115}$ PIRA (Provisional Irish Republican Army) üyeleriyle yapılan görüşmelerde, ideolojiden ziyade o tarihteki siyasi durum ve toplumsal bağlantının radikalleşme sürecinde belirleyici bir değişken olduğu ortaya çıkmıştır. Bununla birlikte, 1970'li yıllardan 1990'ların sonuna kadar, ETA'ya (Euskadi Ta Askatasuna) üye olan kişilerin çoğunluğu, terörist gruba katılmadan önce etnik milliyetçi ideoloji fikrini benimsemiştir. Bkz. European Commission's Expert Group on Violent Radicalisation, a.g.e., s. 15.
} 
74

Güvenlik Stratejileri

Y11: 14

Sayı: 28

yakınmalar, ne radikalleşme süreçleri içerisinde şiddetin gelişmesinde, ne de gerçek anlamda terörist eylemlere katılımda yeterli değildir. Ayrıca, ideolojilerin etkili olduğu ve siyasal firsat yapılarının ifade ve zorlayıc1 şiddete izin verdiği durumlarda şiddete başvurma olasıllığı artmaktadır. Bu şekilde, bireyin birincil ve ikincil sosyalleşmesinin gerçekleştiği siyasi ve sosyal çevre, büyük oranda radikalleşme süreçlerinin şekillenmesinde etkili olmaktadır. ${ }^{116}$

Radikalleşme sürecinde bir mekanizma olarak ideoloji, bazıları için şiddet girişimlerinde önemli olmakla birlikte, ideolojik fikirlere kayıtsız kalan kişiler için önemsiz olabilmektedir. $\mathrm{Bu}$ anlamda, örneğin, aşırı sağcı teröristlerin birçoğunun ideolojik bilgisi çok azken, benzer şekilde, din temelli terörist grupların üyelerinin dinî bilgileri yetersiz ve genellikle de çarpıktır. Bunun yanında, çoğunlukla intikam duyguları en önemli dürtü olarak ortaya çıkarken, ideoloji bazen sonraki süreçte rasyonelleştirme ve mantığa bürümede kullanılan bir araç olarak ortaya çıkar. Bu şekilde belirli bir sosyal çevre veya radikal kişilerden oluşan gruplar ve ağlar gibi durumsal faktörler, ideolojik faktörlerden daha baskın çıkarak birçok genç aktivisti militanlığa ve nihayetinde terörizme yöneltebilir. ${ }^{117}$

Belirli bir amaç ve ideoloji etrafinda ortaya çıkan terörist faaliyetlerin grup dinamikleri içinde şekillendiği dikkate alındığında, normal bir kişinin amaçları ve arkadaşlıkları için şiddete ve terörizme yönelebilmesi teröre dayalı bir grubun sosyal gücünü ortaya koymaktadır. ${ }^{118}$ Bunun yanında, aktörlerin radikalleşme dereceleri diğer aktörlerin faaliyetlerine tepki olarak gelişebilir. Bu şekilde, bireylerin, grupların ve kamuoyunun radikalleşme süreçleri; devlet ya da devlet dışı aktörlerin aralarındaki ilişkilerdeki etki-tepki döngüsü kapsamında geliştiği ve eylem ile faaliyetlerine bağlı olarak iki tarafın radikalleşmesi şeklinde devam ettiği görülmektedir. ${ }^{119} \mathrm{Bu}$ anlamda,

\footnotetext{
${ }^{116}$ European Commission's Expert Group on Violent Radicalisation, a.g.e., s. 14-15.

${ }^{117}$ Alex P. Schmid, a.g.e., s. 28.

${ }^{118}$ Clark McCauley, a.g.e., s. 29.

${ }^{119}$ Clark McCauley ve Sophia Moskalenko, a.g.e., s. 430.
} 
tepkisel ilişkilerin anlaşılmasının şiddetin araçsallaştırılmasında grupların dışındaki aktörler ile etkileşimlerinin önemli olduğuna işaret edilmektedir.

Terörizme giden radikalleşme sürecinde bazı bireyler bir sosyal gruba katıldıktan sonra grubun üyesi olarak şiddeti destekleyen bir ideoloji ile karşılaşmaktadır. Bu şekilde, yeni bir gruba katılan bireyler, grup dinamikleri içerisinde kendilerini kabul ettirmek ve grup içerisinde değer bulmak için kolektif davranışlara yönelebilir. Artık grubun üyesi olarak grubun yararına olan önemli fedakârlıklarda bulunma gerekliliği duymaya başlar. ${ }^{120}$ Terörist örgütlere katılan bireylerin örgütlerin değerlerini, kurallarını ve inançlarını öğrenme süreçleri; teröristin psikolojik yapısı ile ideolojik faktörler, grup süreçleri, örgütün grup ve hücre yapılanması ile örgütün sosyokültürel ortamlarının karşılıklı etkileşimlerini ihtiva eder. Terörist grupların yapıları, üyelerine ait olma ve kendilerini değerli hissetme duygusu ile terörist eylemlerin ahlaken meşru ve grup amaçlarının en önemli husus olduğunu kabul eden bir inanç sistemi sunar. ${ }^{121}$ Sprinzak, grup içinde radikalleşmenin derinleştikçe kolektif grup kimliklerinin bireysel kimliklerin önüne geçtiğini ve grup kimliklerinin en üst noktaya ulaştığını ifade etmiştir.

Grup amaçlarının meşruluğu veya faaliyetleri hakkında şüpheye yer yoktur; grup kararını sorgulayan kişi gruptan kovulmaya varan bir davranışla karşı karşıya kalabilir. Gerçekten grup içindeki korku çok fazladır ve gruptan ayrılmak ancak ölüm ile gerçekleşebilir. Grup içi itaati sağlamak için öldürmeye varan yoğun baskı unsurları mevcuttur. Grupların ideolojisi, otoritenin sağlanmasında ve grup içi itaat ortamının oluşturulmasında çok önemli bir role sahiptir. Herhangi bir konuda sorgulayıcı yaklaşımlar ortaya çıktığında, mutlak ideoloji

\footnotetext{
${ }^{120}$ Arie W. Kruglanski vd., a.g.e., s. 81 .

${ }^{121}$ Rex A. Hudson, a.g.e., ss.3 4-35.

${ }^{122}$ A.g.e., s. 5.
} 
76

Güvenlik

Stratejileri

Y11: 14

Sayı: 28

çoğunlukla mantıksal meşrulaştırma aracı olarak ön plana çıkar. ${ }^{123}$

Bir kişi kendi kimliğini bir grup içinde tanımladığında, grubun ahlaki kuralları, gruptaki her bireyin ahlaki kuralları hâline gelir. Grup ideolojisinin yorumlanmasıyla tanımlanan ahlak, grubun ahlakı hâline gelir ve bütün grubun itaatkâr üyeleri üzerinde otorite sağlar. Eğer ideoloji "Bizim problemlerimizin sorumlusu onlardır" prensibiyle "onların" yok edilmesi gerektiğine işaret ederse, bu husus sadece meşru görülmekle kalmaz, aynı zamanda ahlaki bir zorunluluk olarak kabul edilir. ${ }^{124}$ Grup içindeki bireylerin aşırılığa yönelmesi ve bağlılıklarının derinleşmesi, öncelikli olarak grup içi sosyalleşme ile gelişir. Grup liderlerinin etkileri ve grup dinamikleri ile bireylerin düşünce, duygu ve davranışları şekillendirilerek grup dışındaki bireylere karş1 tahammülsüzlük yaratılır. ${ }^{125}$ Grup düşüncesi konusundaki araştırmalar, grupça alınan kararların bireylerin yalnız başlarına aldıkları kararlardan çok daha riskli olduğunu göstermektedir. ${ }^{126}$ Terörizme giden yolda başlangıçtaki inançlar ve bağlılıklar, haksızlık olarak kabul edilen duruma karşı harekete dönüşebilir ve grup tartışmaları ile grup içindeki statü rekabeti, grubu daha radikal fikirlere ve daha aşırı şiddet eylemlerine yöneltebilir. ${ }^{127}$

Yeraltı terörist hücrelerin üyeleri, örgütü yaşamlarının ilk sırasına koydukları anda diğer bağlantıları tamamen kopar ya da azalır. Tek gruba ait olma gücü çok önemli bir hâle gelerek, her çeşit bireysel ve ahlaki değeri kaplar. Artık bu güç, düşmana karşı uygulanacak şiddeti sadece kabul edilebilir değil, gerekli k1lar. Terörist örgütlerin mensuplarının fiziki olarak dağınık faaliyet göstermelerine rağmen bir

${ }^{123}$ Jerrold M. Post, "Terrorist Psycho-logic: Terrorist Behavior as a Product of Psychological Forces", Walter Reich (Ed.), Origins of Terrorism: Physchologies, Ideologies, Theologies, States of Mind, The Woodrow Wilson Center Press, Washington, 1998, 25-40, ss. 33-34.

${ }^{124}$ A.g.e., s. 34.

${ }^{125}$ Randy Borum, a.g.e., s. 45.

${ }^{126}$ Jerrold M. Post, a.g.e., s. 37.

${ }^{127}$ Clark McCauley, a.g.e., s.22. 
gruba ait olma duyguları ile oluşan sosyal dünyadaki ideolojik amaçları, tahmin edilemeyecek kadar önemli ve güçlü hâle gelebilir. Artık teröristler bu noktada, hareketlerinin "iyinin zaferini" gerçekleştirilebileceği dünya olarak tehlikeli bir şekilde "iyi" ve "kötü" olarak algılamaya başlar. "İyinin zaferi”" ve "şeytanın" yok edilmesi için özellikle radikal hareketlere girişilmesinin gerekli olduğu kabul edilir. ${ }^{128}$

Radikalleşme süreçlerinde şiddetin araçsallaştırılması, grup içi dinamiklerin yanında grup dişı dinamiklerin etkisiyle de gelişebilir. Nihayetinde terörist örgütlerin grup dinamikleri, hedef kitleler ile aktörlerin örgütlerin gerçekleştirdikleri eylemlere tepkileri ve amaçları ile hedeflere yaklaşımlarına göre etki-tepki mekanizması çerçevesinde şekillenir. ${ }^{129}$ Devletler, terörist örgütlerin davranışlarını etkilemek amacıyla hem bastırıcı, hem de uzlaşmacı politikaları uygulamaya koyabilir. $\mathrm{Bu}$ anlamda, terörist örgütlerin davranışlarını devletlerin davranışlarından bağımsız olarak ele almak zordur. ${ }^{130}$ Nitekim, bu durumu etki tepki mekanizması olarak ifade eden Crenshaw ve Marighella, teröristlerin en önemli amaçlarının özellikle devleti provoke ederek amaçlarına sempati duyanlar arasındaki kararsızları etkilemek ve harekete geçirmek olduğu şeklinde özetlemiştir. ${ }^{131}$ Terörist örgütler etki tepki mekanizmasını; sembolik veya sivil hedeflere karşı sürekli şiddet içeren saldırılar gerçekleştirerek korku yaymak, siyasi haksızlıklara dikkat çekmek ve uyguladıkları şiddete aşırı şiddetle karş1lık verilmesini provoke etmek suretiyle harekete geçirmeye çalışır. Terörist örgütler düşman olarak tanımladıkları aktörlerin aşırı tepki vermelerini sağlayarak sözde "gerçek kötü yüzlerini" ortaya çıkarmayı ve özellikle hangi kötü şartlar nedeniyle silaha sarılmak zorunda kaldıkları konusuna dikkat çekerek ülke içinde ve dışında sempati oluşturma imkânı bulabilmeyi umut eder. ${ }^{132}$

\footnotetext{
${ }^{128}$ A.g.e., ss. 19-21.

${ }^{129}$ Mehmet Kurum, a.g.e., s. 75.

${ }^{130}$ Katharine A. Boyd, a.g.e., ss. 88.

${ }^{131}$ Clark McCauley, a.g.e., s. 62.

132 James Kiras, "Terrorism and Irregular Warfare", John Baylis vd. (Eds.), Strategy in
} 
Güvenlik Stratejileri

Y11: 14

Sayı: 28

Teröristlerin mantığına göre, yönetim, sürekli terör eylemleriyle teyakkuz durumuna geçirilerek daha şiddetli ve dikkatsiz bir şekilde karşılık vermeye zorlanır. Bu durumda kitleler üzerinde oluşan şiddetli baskıdan olumsuz etkilenenler, teröristler tarafından kolayca harekete geçirilebilir duruma gelir. Nitekim ETA mensupları bu durumu şu şekilde ifade etmiştir: "Düşman büyük bir hayvan gibi sağa sola körü körüne saldırır. Bu noktada biz en önemli amaçlarımızdan biri olan düşmanı binlerce zulüm ve acımasızlık içeren eylemler yaptırmayı başarmış oluruz. Toplumun çoğunluğu masumdur. Bu durumda az ya da çok pasif ve bekleyen insanlar öfkeli hâle gelir ve tepki olarak da bize döner. Bundan daha iyi bir sonuç bekleyemeyiz."133

Aynı şekilde, kendilerine neden örgüte katıldıkları sorulan PIRA'nın kadın teröristlerinin, İngiliz askerlerinin küfürlü konuşmaları ile olumsuz davranışlarının kendilerinde kin ve nefret hislerinin oluşmasına ve bunun da PIRA'nın uyguladığ kabul edilmesi inancına neden olduğunu belirtmesi dikkat çekicidir. ${ }^{134}$ Benzer şekilde, 1970'li yıllarda İngiliz ordusu tarafindan teröristlerin silahlı faaliyetlerini engellemek ve terörist şüphelilerini tespit etmek için uygulanan "durdur ve ara" taktiklerinin, Kuzey İrlandalı Katoliklerin çoğunluğu üzerinde aşağılanma hisleri uyandırdığı ve bu hislerin PIRA'ya katılımların artmasında önemli etkenlerden biri olduğu ifade edilmiştir. ${ }^{135}$

Terörist grupların motivasyonları zaman içinde düşük şiddet seviyesinden, yaygın nefret ve öfke duygularına bağlı olarak derin

the Contemporary World: An Introduction to Strategic Studies, Oxford University Press, Oxford, 2007, 185-207, ss. 187-188.

${ }^{133}$ Brian M. Jenkins,"International Terrorism: The Other World War"; Charles W. Kegley (Ed.), The New Global Terrorism: Characteristics, Causes and Controls, Prentice Hall, New Jersey, 2003, 15-26, ss. 22-23.

${ }^{134}$ Rex A. Hudson, a.g.e., s. 57.

${ }^{135}$ J.P.I.A.G. Charvat, "Terrorism: Today and in the Future with Possible Aspects (Conventional, Bio, WMD, Cyber, etc.)", Centre of Excellence Defence Against Terrorism (Ed.), Organizational and Psychological Aspects of Terrorism, IOS Press, Ankara, 2008, 23-36, s. 30. 
ideolojik odaklanma, grup bütünlügü, düşmanlarına karşı aşırı tepki verme ve/veya karizmatik lidere bağlılık nedenleriyle en yıkıcı seviyeye dönüşebilmektedir. ${ }^{136}$ Crenshaw, terörist örgütlerin ilk nesillerini bir araya getiren dürtülerin genel anlamda yoksunluk ve haksızlık duyguları etrafında şekillenirken, sonraki nesillerde zamanla terörizm karşıtı mücadeleye tepki, intikam ve organizasyonun devamlılığı etrafında şekillenmeye başladığını belirtmiştir. ${ }^{137}$ Bunun yanında, güvenlik güçleri tarafından terörist örgütlere yönelik operasyonlar gerçekleştirildikçe, teröristlerin grup içi bağll1ıkları artma eğilimi gösterebilmektedir. ${ }^{138}$

Terörist örgütlerin eylemlerinin şiddeti, mücadele ettikleri aktörlerin tepkilerine ve örgütlerin eylem kapasitelerine bağlı olarak zaman içinde artabilmektedir. Özellikle mücadele ettikleri aktörlerin tepkileri şiddetlendikçe, örgütler söz konusu şiddete karşı kendilerini koruyacak ve karşı tepki verebilecek şekilde eylem kapasitelerini geliştirmeye çalışır. Teröristler öldürülmeye veya yakalanarak cezaevlerine konulmaya başladıkça, arkadaşlarını kaybeden diğer elemanlar, grup içi dinamiklerin etkisiyle intikam duygularıyla hareket etmeye ve daha öldürücü eylemler yapmaya yönelebilir. Böylece, örgütlerin başlangıçtaki siyasi amaçlarına intikam alma ve cezaevindeki örgüt elemanlarını kurtarmak gibi yeni amaçlar da eklenmiş olur. ${ }^{139}$

\footnotetext{
${ }^{136}$ Gunaratna, birçok terörist grubun daha az seviyede saldırı eylemleriyle faaliyetlerine başlayıp daha sonraki baskı ve diğer dış olayların etkisiyle çok daha ölümcül saldırılara yöneldiği hipotezinin, mevcut bilgiler 1şığında sınırlı olarak desteklendiğini öne sürmüştür. Bkz. Dipak K. Gupta, "Exploring Roots of Terrorism", Tore Bjorgo (Ed.), Root Causes of Terrorism: Myths, Reality and Ways Forward, Routledge, Londra, 2005, 16-32, s. 25.

${ }^{137}$ J. Neil Smelser, The Faces of Terrorism: Social and Psychological Dimensions, Princeton University Press, New Jersey, 2007, ss. 95-96.

${ }^{138}$ Rex A. Hudson, a.g.e., s. 37.

${ }^{139}$ Mehmet Kurum, a.g.e., s. 76. Nitekim 1970 yılında Kızıl Ordu Fraksiyonu [Red Army Fraction $(R A F)]$ üyelerine yönelik tutuklamalar başlayınca, polise karşı öldürücü saldırılar ile seri bombalama eylemleri başlamış ve cezaevindeki mahkûmlara özgürlük adına kundaklama eylemleri gerçekleştirilmesi çağrısı yapan bildiriler dağıtılmışır. Bkz. Peter H. Merkl, "West German Left-Wing Terrorism", Martha Crenshaw (Ed.), Terrorism in Context, (3.Bask1), The Pennsylvania State University Press, Pennsylvania, 2003, 160-210, ss. $182-183$.
} 
Terörist örgütlerin eylemlerine karşı düşman olarak tanımlanan

Güvenlik

Stratejileri

Y1l: 14

Sayı: 28 otorite veya kitlelerin aşırı tepki göstererek şiddet ile karşıllk vermeleri, kendilerinin uyguladıkları şiddetin geri planda kalmasına ve bu şekilde de amaç ile niyetlerinin yandaş kitleler tarafindan meşru kabul edilmesine hizmet eder. ${ }^{140}$ Ayrıca grup dışı tehditler, grup içi bağl1lıkta önemli bir faktör olarak ortaya çıkarken, amaçlarını ve gruplarını savunmak için şiddetin gerekli olduğu öne sürülerek saldırı eylemlerinin kendilerini savunmak amacıyla gerçekleştirildiği şeklinde rasyonelize edilmeye çalışılır. ${ }^{141}$

\section{Sonuç}

11 Eylül 2001 saldırıları ile farklı bir boyut kazanan terörizm tehdidi, daha önceden terörist saldırıların doğrudan hedefi olmamış ülke ve toplumları da içine alacak şekilde genişleyerek küresel boyutta etki yaratmaya başlamıştır. Bu tehdide karşı gösterilen uluslararası çabaların etkinliği konusundaki tartışmalar, terörizmin henüz ortaya çıkmadan nasıl önlenebileceği konusunda kapsamlı araştırmalar yapılmasına neden olmuştur. Bu çerçevede, terörizmin arka planını oluşturan radikalizm ve aşırıcılık ile bunlarla mücadele yöntemlerine odaklanan yaklaşımlar terörizmi önleyici araç olarak ön plana çıkmıştır. Genellikle Batı ülkelerinin etkisinde gelişen bu yaklaşımlar, temelde ülke ve toplumların kendi tehdit algilamalarına göre tek taraflı ve subjektif olarak gelişmiştir. Bu bakış açısı radikalizm, aşırıcılık ve terörizme ilişkin kavramsallaştırmalar ile yaklaşımlarda karmaşıklığa neden olmuştur. Öncelikle bu muğlak durumu ortadan kaldırmak için, söz konusu kavramların hem etimolojik açıdan, hem de farklı boyutlarda yapılan kavramsallaştırmalar bağlamında ele alınması, bu terimler arasındaki farklılıklar ve benzerlikler ile birbirleri arasındaki ilişkilerin ortaya konulması gerekmektedir. Bu konuda literatürde yer alan tartışmalar incelendiğinde, radikalizmin aşırıcılık, fanatizm ve fundamentalizmi içine alan daha geniş bir kavram olduğu ve şiddetin

\footnotetext{
${ }^{140}$ A.g.e., s. 77.

${ }^{141}$ Randy Borum, a.g.e., s. 45.
} 
araç olarak benimsenmeye başladığı noktada terörizme dönüştüğü görülmektedir.

Terörizme giden radikalleşme sürecinde şiddetin benimsenme derecesi farklı olabilmektedir. Terörist örgütlerin içerisinde silahlı eylemlere katılan teröristlerin yanında, örgütün ideolojisine bağlı fakat şiddeti zaman zaman araç olarak kullanan destekçiler ile örgütün ideolojisini benimseyen ancak şiddeti reddeden sempatizan kitlesi olmak üzere üç farklı gruptan bahsedilebilir. Bu gruplar arasında kesin sinırlar çizmek mümkün değildir. Örneğin, örgüte sempati besleyen bir kişi veya grup zaman içerisinde şiddeti araç olarak benimseyip destekçi veya doğrudan silahlı terörist seviyesine geçiş yapabilmektedir. Söz konusu geçişlerin bir anda ortaya çıkmadığı, mevcut maddi koşullara ilişkin algılamaya bağlı olarak haksızlık ve mağduriyet duygularının gelişmesine göre şekillendiği görülmektedir. Mağduriyet algısının giderilmesine yönelik çözüm bulunamayacağı inanc1, mağduriyetin sorumlusu olarak görülen kişi, grup veya aktörlere karşı saldırganlığın yöneltilmesine ve nihayetinde şiddet ile terörizmin meşru olarak görülmesine neden olabilmektedir. Bu noktada "bize karşı onlar" algısıyla gelişen "iyilerin kötülere karşı mücadelesi” çerçevesinde her türlü terörist eylem meşru ve hatta kimi zaman gerekli olarak görülmeye başlar.

Radikal fikirleri savunan ve aşırıcılığa yönelen herkesin şiddeti benimseyerek terörizme yönelmediği, şiddetin benimsenmesi ve araçsallaştırılması noktasında grupların ideolojileri ile grupların iç ve dış dinamiklerinin etkili olduğu görülmektedir. Kişi veya grupların benimsedikleri ideolojiler, grupların amaç ve hedeflerine ulaşmak için şiddetin meşru veya gerekli ve hatta bazı durumlarda kutsal kabul edilerek araçsallaştırılmasında önemli belirleyici faktörlerden biri olarak ortaya çıkmaktadır. Nitekim farklı ideolojilere sahip birçok terörist örgütün şiddeti meşrulaştırma ve gerekçelendirme söylemleri ile şiddeti kullanma taktik ve tekniklerinin farklılıkları bu durumu açıkça göstermektedir.

Terörist örgülerin benimsedikleri ideolojilerin yanında grup içi ve dişı dinamikleri de şiddetin araçsallaştırmasında önemli bir etken olarak ortaya çıkmaktadır. Bazı durumlarda ideolojiye kayıtsız kalan kişiler dahi bir grubun üyesi olduktan sonra grup içi sosyalleşme 
Güvenlik Stratejileri

Y11: 14

Sayı: 28 süreçleriyle radikalleşmeye ve aşırılığa yönelebilir. Grup içinde gelişen inançlar ve bağl1lıklar haksızlık olarak algılanan durumlarda grup içi dinamiklerin etkisiyle daha radikal fikirlere ve aşırılığa, nihayetinde şiddeti araç olarak benimseyen bir harekete evrilebilir. Bununla birlikte, grubun dışından, gruba veya temsil ettiğini iddia ettiği kitlelere yönelen etkilere göre tepkisel olarak şiddet araç olarak benimsenebilir. Özellikle devletlerin terörist örgüt ve yandaşlarının eylem ve faaliyetlerine karşı sadece şiddet içeren aşırı ve gereksiz baskıcı araçları kullanmaları, örgüt tarafından tepkisel anlamda şiddet kullanılmasının gerekçesini ve meşru zeminini oluşturabilir.

Birçok faktöre bağlı olarak ortaya çıkan ve gelişen radikalleşme sürecinin aşırıcılığa ve sonrasında şiddetin araçsallaştırılarak terörizme dönüşmesinde; bazen ideoloji önemli bir etken olurken, bazen de grup içi ve dışı dinamikler önemli etkenler olarak ortaya çıkabilmektedir. $\mathrm{Bu}$ çalışma kapsamında ortaya konan terörizme dönüşen radikalleşme süreçlerine ideolojinin ve grup dinamiklerinin hangi durumlarda nasıl etki yarattığının anlaşılması; terörizmle mücadelede terörist örgütlere olan sempati ile desteğin azaltılması, katılımların engellenmesi ve örgütlere katılmış olan kişilerin bağlılık ve inançlarının azaltılarak ayrılmalara yöneltilmesi konularında yaklaşım, strateji ve uygulamaların geliştirilmesinde önemli katkılar sağlayacaktır.

\section{Summary}

After 9/11 attacks, terrorism became a global threat by including and broadening into countries and societies, which have previously never been targeted directly by terrorist organizations. The discussions on the effectiveness of counter measures developed to defeat this security threat caused academicians and experts to conduct comprehensive studies to explore how to defeat terrorism before it emerges. So, the approaches focused on radicalism and extremism; the counter measures to defeat them have stood out as a preventive tool for counter terrorism. These new approaches mostly dominated by the Western perspectives have progressed unilaterally and subjectively based on the threat perceptions of countries and societies. These 
uniletarel and subjective approaches lead to an ambiguity for the conceptualization of radicalism, extremism, and terrorism.

In this article, we aim to make a descriptive analysis about radicalism, extremism, and terrorism; to reveal relations among the related terms; to examine in which situations individuals and groups use and instrumentalize violence. Within this context, firstly, we handled radicalism and related terms, historical perspectives and different approaches on radicalism. Secondly, we tried to explain how violence was adopted through the process in which radical thoughts and actions were converted into extremism and terrorism.

Having reviewed the literature on the subject, it can be argued that radicalism is a broader concept covering fanatism and fundamentalism, and it can turn into terrorism where violence starts to be used as an instrument. The most distinctive element in relation with the conceptual discussions is "threshold of violence". While many people have radical ideas and beliefs, many terrorists do not have deep ideological ideas and might not be radicalized. Having rised through the extreme belief and ideas that justify violence, radicalism is one of the paths leading to terrorism. "Extremism", "fundamentalism", and "fanatism" are different types of radicalism. The concepts of radicalism, extremism, fundamentalism and fanatism can be defined in the area of terrorism, once they start to use violence in accordance with expected aim and target.

The degree of adopting violence in the radicalisation process heading to terrorism can be different. We can mention three different groups: terrorists who take part in the violent acts within the organisations, supporters who are devoted to the ideology but rarely use violence, and sempathizers who adopt the ideology but reject violence. There are no certain boundaries among these groups. For instance, the individuals and groups who are symphatizers and who adopt violence as an instrument in time can become supporters or terrorists. These conversions take time; however feeling of injustice and victimization along with the grievance in social environment can accelerate this conversion process. The belief that no solution can be found for the perception of victimization and injustice can lead the 
Güvenlik

Stratejileri

Y11: 14

Sayı: 28 aggression towards the people, who are considered as responsible for their grievance, and ultimately violence can be justified and used against the categorized enemy. At this point, all kinds of terrorist acts, which are supported by the perception of "us versus them" and "fighting of good against bad", start to be seen as legitimate and sometimes even necessary.

While not all individuals, who defend radical ideas and tend to extremism, resort to terrorism through adopting violence; it is mostly observed that group ideology along with the out-group and in-group dynamics can be effective in adoption and instrumentalization of violence. The distinctive factor in instrumentalization of violence is that ideology of groups and individuals accepting use of violence as legitimate or necessary, or even sacred for reaching their aims and targets. Hence, terrorist discourse in justifying and legitimazing violence, tactics, and techniques in using violence can differentiate according to the ideology that the terrorist organisation adopts.

In addition to the ideologies adopted by the terrorist groups, the in-group and out-group dynamics also appear as an important factor in the instrumentalization of violence. In some cases, even those, who are indifferent to the ideology, can be exposed to radicalization and extermism through in-group socialization process after they become members of the group. The beliefs and loyalties that developed within the group by means of in-group dynamics can evolve into more radical ideas, extremism, and ultimately as a means of violence. However, due to the effects directed at the group or the masses that claim to represent the group from the outside of the group, it can be adopted reactionally as a means of violence. In particular, the use of excessive and unnecessary oppressive tools by the state against the acts and activities of the terrorist organization and its supporters can reactionally be the justification and legitimate basis for the use of violence by the organization.

While ideology is an important factor in the radicalization process, which includes respectively transformation of radicalism into the extremism and terrorism through instrumentalization of violence, in-group and out-group dynamics, in different situations and times, can 
be important factors as well. To understand how the ideology and group dynamics are affected by the radicalization processes that have emerged in the context of this study will make significant contributions to the development of approaches, strategies and practices in counterterrorism, especially in prevention of participation, reduction of the sympathy, support, and commitment to the terrorist organizations.

\section{Kaynakça}

\section{Kitaplar}

ALIMI, Eitan Y. vd., The Dynamics of Radicalization: A Relational and Comparative Perspective, Oxford University Press, Oxford, 2015. BECK, Colin J., Radicals, Revolutionaries, and Terrorists, Polity Press, Cambridge UK, 2015.

DEMIR, Cenker Korhan, Sebeplerinden Mücadele Yöntemlerine Avrupa'da Etnik Ayrılıkçı Terörizmin Analizi: PIRA, ETA, PKK, Nobel Akademik Yayıncılık, Ankara, 2017.

HEYWOOD, Andrew, Siyasi İdeolojiler: Bir Giriş, (5. Bask1), (Çev. Ahmet Kemal Bayram, Özgür Tüfekçi, Hüsamettin İnaç, Şeyma Akın ve Buğra Kalkan), Adres Yayınları, Ankara, 2013.

HUDSON, Rex A., The Sociology and Psychology of Terrorism: Who Becomes A Terrorist and Why?, A Report Prepared Under an Interagency Agreement by the Federal Research Division, Library of Congress, Ekim 1999.

KURUM, Mehmet, Terörist Örgütlerin Güvenli Ortamlart ve PKK, Nobel Akademik Yayınc1lık, Ankara, 2017.

LUTZ, James M. ve Brenda J. Lutz, Global Terrorism, (2. Bask1), Routledge, Londra, 2008. 
MACALUSO, Agnese, From Countering to Preventing

Güvenlik

Stratejileri

Y11: 14

Sayı: 28 Radicalization Through Education: Limits and Opportunities, Working Paper 18, The Hague Institute for Global Justice, The Hague The Netherlands, October 2016.

SCHMID, Alex P., Radicalisation, De-Radicalisation, CounterRadicalisation: A Conceptual Discussion and Literature Review, The International Centre for Counter-Terrorism (ICCT) Research Paper, The Hague, 2013.

SMELSER, J. Neil, The Faces of Terrorism: Social and Psychological Dimensions, Princeton University Press, New Jersey, 2007.

STEPANOVA, Ekaterina, Terrorism in Asymmetrical Conflict: Ideological and Structural Aspects, SIPRI Research Report No.23, Oxford University Press, New York, 2008.

Türk Dil Kurumu (TDK), Türkçe Sözllük, (10.Bask1), Ankara, 2005.

Türkiye Barolar Birliği, Türkiye ve Terörizm, Rapor, TBB Yayınları, Ankara, Haziran 2006.

WILKINSON, Paul, Political Terrorism, The Macmillan Press, Londra,1974.

\section{Makaleler}

ABBAS, Tahir, "The Symbiotic Relationship Between Islamophobia and Radicalisation", Critical Studies on Terrorism, 2012, Cilt: 5, No.3, 345-358.

ABBAS, Tahir, "Ethnicity and Politics in Contextualising Far Right and Islamist Extremism", Perspectives on Terrorism, 2017, Cilt: 11, No. 3, 54-61.

AYDIN, Mustafa, "The Connection Between Radicalism, Extremism and Terrorism", 31 December 2015, http://www.hurriyetdailynews.com/ theconnection-between-radicalism-extremism-and-terrorism.aspx?PageID $=238 \& N I D=93231 \&$ NewsCatID=468 (Erişim Tarihi: 03.03.2017).

BAŞEREN, Sertaç, "Terörizm ve Uluslararası İlişkiler", Stratejik Araşturmalar Dergisi, Şubat 2003, Cilt: 1, No.151-58.

BORUM, Randy, "Radicalization into Violent Extremism II: A Review of Conceptual Models and Empirical Research", Journal of Strategic Security, 2011, Cilt: 4, No. 4, 37-62. 
BOYD, Katharine A., "Group-level Predictors of Politicial and Religiously Motivated Violence", Gary LaFree ve Joshua Freilich (Eds.), The Handbook of the Criminology of Terrorism, Wiley Blackwell, West Sussex, 2017, 77-92.

BROWN, Katherine E. ve Tania Saeed, "Radicalization and CounterRadicalization at British Universities: Muslim Encounters and Alternatives", Ethnic and Racial Studies, 2015, Cilt: 38, No:11, 19521968.

CHALIAND Gérard ve Arnaud Blin, "The Invention of Modern Terror", Gérard CHALIAND ve Arnaud BLIN (Eds.), The History of Terrorism: From Antiquity to Al Qaeda, (Çev. Edward SCHNEIDER, Kathryn PULVER ve Jesse BROWNER), University of California Press Ltd., Londra, 2007, 95-112.

CHARVAT, J.P.I.A.G., "Terrorism: Today and in the Future with Possible Aspects (Conventional, Bio, WMD, Cyber, etc.)",Centre of Excellence Defence Against Terrorism (Ed.), Organizational and Psychological Aspects of Terrorism, IOS Press, Ankara, 2008, 23-36. CRENSHAW, Martha, "Theories of Terrorism: Instrumental and Organizational Approaches", David Rapoport (Ed.), Inside Terrorist Organizations, Frank Cass Publishers, Londra, 2001, 13-31.

CRONIN, Audrey Kurth, "Behind the Curve: Globalization and International Terrorism", Michael E. Brown vd. (Eds.), Contending with Terrorism: Roots, Straegies, and Responses, The MIT Press, Londra, 2010, 28-56.

DAHRI, Noor. "Op-Ed: Mind Space Methodology and De-Radicalisation Model", 13 Mart 2017, http://www.jerusalemonline.com/blogs/noordahri/op-ed-mind-space-methodology-and-de-radica lisation-model27218, (Erişim Tarihi: 11.04.2017).

DRAKE, C. J. M., "The Role of Ideology in Terrorists' Target Selection", Terrorism and Political Violence, 1998, Cilt: 10, No. 2, 53-85.

European Commission's Expert Group on Violent Radicalisation, "Radicalisation Processes Leading to Acts of Terrorism", 15 May 2008, http://www.rikcoolsaet.be/files/art_ip_wz/Expert\%20Group \%20Report\% 20Violent\%20Radicalisation\%20FINAL.pdf(Erişim Tarihi: 12.10.2017). 
GERWEHR, Scott ve Kirk Hubbard, "What Is Terrorism: Key Elements and History", Bruce BONGAR vd. (Eds.), Psychology of Terrorism, Oxford University Press, New York, 2007, 87-100.

GUPTA, Dipak K., "Exploring Roots of Terrorism", Tore BJORGO (Ed.), Root Causes of Terrorism: Myths, Reality and Ways Forward, Routledge, Londra, 2005, 16-32.

HORGAN, John, "The Social and Psychological Characteristics of Terrorism and Terrorists", Tore Bjorgo (Ed.), Root Causes of Terrorism: Myths, Reality and Ways Forward, Routledge, Londra, 2005, 44-53.

JENKINS, Brian M., "International Terrorism: The Other World War", Charles W. Kegley (Ed.), The New Global Terrorism: Characteristics, Causes and Controls, Prentice Hall, New Jersey, 2003, 15-26.

KIRAS, James, "Terrorism and Irregular Warfare", John BAYLIS vd. (Eds.), Strategy in the Contemporary World: An Introduction to Strategic Studies, Oxford University Press, Oxford, 2007, 185-207.

KRUGLANSKI, Arie W. vd., "The Psychology of Radicalization and Deradicalization: How Significance Quest Impacts Violent Extremism", Advances in Political Psychology, 2014, Cilt: 35, No. 1, 69-93.

KUNDNANI, A., "Radicalisation: The Journey of a Concept" Race \& Class, 2012, Cilt: 54, No. 2, 3-25.

LYNCH, Orla, "British Muslim Youth: Radicalisation, Terrorism and the Construction of the "Other"“", Critical Studies on Terrorism, 2013, Cilt: 6, No. 2, 241-261.

LYONS-PADILLA, S. vd., "Belonging Nowhere: Marginalization \& Radicalization Risk Among Muslim Immigrants" Behavioral Science \& Policy, 2015, Cilt: 1, No. 2, 1-12.

McCAULEY, Clark, "Psychological Issues in Understanding Terrorism and the Response to Terrorism", Bruce Bongar vd. (Eds.), Psychology of Terrorism, Oxford University Press, New York, 2007, 13-31.

McCAULEY, Clark, "War Versus Justice in Response to Terrorist Attacks: Competing Frames and Their Imlications", Bruce BONGAR vd. (Eds.), Psychology of Terrorism, Oxford University Press, New York, 2007a, 56-65. 
McCAULEY, Clark ve Sophia Moskalenko, "Mechanisms of Political Radicalization: Pathways Toward Terrorism", Terrorism and Political Violence, 2008, Cilt: 20, No. 3, 415-433.

MERKL, Peter H., "West German Left-Wing Terrorism", Martha CRENSHAW (Ed.), Terrorism in Context, (3.Bask1), The Pennsylvania State University Press, Pennsylvania, 2003, 160-210.

MOGHADDAM, Fathali, "The Staircase to Terrorism", American Psychologist, 2005, Cilt: 60, No. 2, 161-169.

MOSKALENKO, Sophia ve Clark McCauley, "Measuring Political Mobilization: The Distinction Between Activism and Radicalism," Terrorism and Political Violence, 2009, Cilt: 21, No. 2, 239-260.

MURO, Diego, "What Does Radicalisation Look Like? Four Visualisations of Socialisation into Violent Extremism" Notes Internacionals CIDOB 163, December 2016. https://www.cidob.org/en/ publications/publication_series/notes_internacionals/n1_163/what_does_ radicalisation_look_like_four_visualisations_of_socialisation_into_violent extremism (Erişim Tarihi: 06.05.2017).

NEUMANN, Peter R., "Introduction", Perspectives on Radicalisation and Political Violence: Papers from the First International Conference on Radicalisation and Political Violence, 17-18 January 2008, International Center for the Study of Radicalisation and Political Violence, Londra, 2008, 3-7.

PORTA, Donetella Della ve Gary Lafree, "Guest Editorial: Processes of Radicalization and De-Radicalization", International Journal of Conflict and Violence (IJCV), 2012, Cilt: 6, No. 1, 4-10.

POST, Jerrold M., "Terrorist Psycho-logic: Terrorist Behavior as a Product of Psychological Forces", Walter Reich (Ed.), Origins of Terrorism: Physchologies, Ideologies, Theologies, States of Mind, The Woodrow Wilson Center Press, Washington, 1998, 25-40.

RAHIMULLAH, Riyad Hosain vd., "Understanding Violent Radicalization Amongst Muslims: A Review of the Literature", Journal of Psychology and Behavioral Science, 2013, Cilt: 1, No. 1, 19-35.

ROY, Olivier, "The Islamization of Radicalism", Rosa Luxemburg Stiftung, 2016, http://www.rosaluxna.org/wp-content/uploads/2016/06/ Newsletter-oliver-roy-ENG-26-01-16.pdf (Erişim Tarihi: 13.09.2018). 
SEDGWICK, Mark, "The Concept of Radicalization as a Source of

Güvenlik Stratejileri

Y11: 14

Sayı: 28
Confusion", Terrorism and Political Violence, 2010, Cilt: 22, No. 4, 479-494.

SOLIMAN, Abdrabo vd., "An Integrative Psychological Model for Radicalism: Evidence from Structural Equation Modeling", Personality and Individual Differences, 2016, No. 95, 127-133.

THORNTON, Thomas Perry, "Terror as a Weapon of Political Agitation", Herry Eckstein (Ed.), Internal War: Problems and Approaches, The Free Press, New York, 1964, 71-99.

TSINTSADZE-MAASS, Eteri ve Richard W. MAASS, "Groupthink and Terrorist Radicalization", Terrorism and Political Violence, 2014, Cilt: 26, No. 5, 735-758.

WEBBER, David ve Arie W. Kruglansk1, "Psychological Factors in Radicalization: A "3N" Approach", Gary Lafree ve Joshua Freilich (Eds.), The Handbook of the Criminology of Terrorism, Wiley Blackwell, West Sussex, 2017, 33-46.

WILNER, Alex S. ve Claire-Jehanne Dubouloz, "Homegrown Terrorism and Transformative Learning: An Interdisciplinary Approach to Understanding Radicalization", Global Change, Peace \& Security, 2010, Cilt: 22, No. 1, 33-51.

Internet Siteleri

English Oxford Living Dictionaries İnternet sitesi, https://en.oxforddictionaries.com/ (Erişim Tarihi: 03.10.2017).

Etimolojik Sözlük İnternet sitesi, https://www.etimolojiturkce.com/ (Erişim Tarihi: 03.10.2017).

Türk Dil Kurumu (TDK) İnternet sitesi, http://www.tdk.gov.tr/ Güncel Türkçe Sözlük, (Erişim Tarihi: 03.10.2017). 